Portland State University

PDXScholar

$12-7-1978$

\title{
The American Efforts to Modernize the Egyptian Army Under Khedive Ismail
}

Robin Joy Love Buxton

Portland State University

Follow this and additional works at: https://pdxscholar.library.pdx.edu/open_access_etds

Part of the Islamic World and Near East History Commons, and the Military History Commons Let us know how access to this document benefits you.

Recommended Citation

Buxton, Robin Joy Love, "The American Efforts to Modernize the Egyptian Army Under Khedive Ismail" (1978). Dissertations and Theses. Paper 3052.

https://doi.org/10.15760/etd.3047

This Thesis is brought to you for free and open access. It has been accepted for inclusion in Dissertations and Theses by an authorized administrator of PDXScholar. Please contact us if we can make this document more accessible: pdxscholar@pdx.edu. 
AN ABSTRACT OF THE THESIS OF Robin Joy Love Buxton for the Master of Arts in History presented December 7, 1978.

Title: The American Efforts to Modernize the Egyptian Army Under Khedive Ismail.

APPROVED BY MEMBERS OF THE THESIS COMMITTEE:

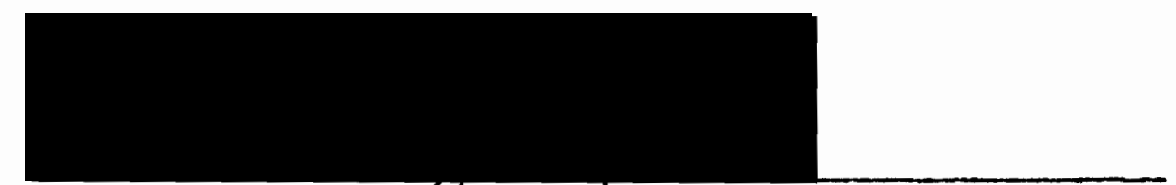

Frederick J. Cox, Ghairman

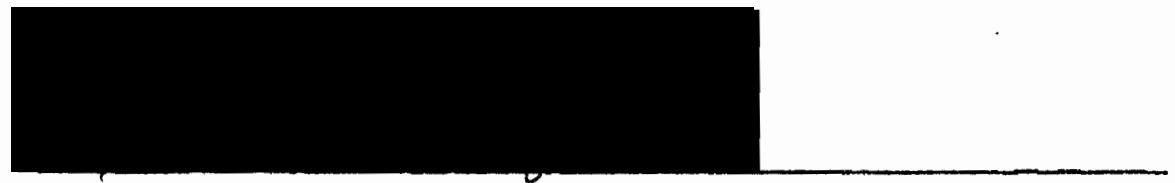

Ann Bennett
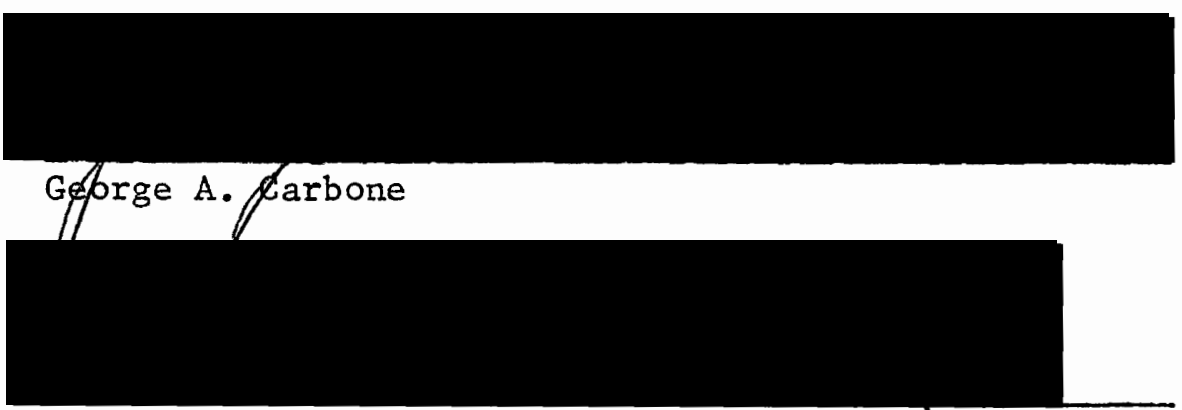

Noury A1-Khalidy

From 1869 to 1878 approximately fifty American military officers were invited to Egypt by Khedive Ismail for the purpose of modernizing the Egyptian army. During that time the American officers led by General Charles P. Stone designed a staff system for the Egyptian army and they established a series of technical schools not only for the staff officers 
but for the rank and file as we11. In addition to the reorganization, the American officers led exploratory expeditions into central Africa, they refortified the Egyptian coastline and they built roads and lighthouses. In conjunction with their expeditions, the officers produced numerous territorial maps, hydrological maps, and assay reports.

Upon reviewing their efforts, however, it must be concluded that the American officers failed in their mission to truly modernize the Egyptian army. Their failure stemmed from three interrelated obstacles that finally coalesced at the Egyptian military defeat in Abyssinia.in 1875. The American officers had been unable to convince the traditional military elite of the Egyptian army, the Turkish and Circassian pashas, that the reorganization was necessary. The pashas persisted in their traditional roles while sabotaging the American efforts wherever possible. The defeat came as a result of their disagreements. Khedive Ismail, who initially supported the American efforts was forced, ultimately, to back his pashas against the American policies due to his tenuous financial position, which had been fully revealed after the Abyssinian defeat. The pashas were his only support against the impending European takeover of his government. With Ismail's suspension of the Egyptian debt payments in April, 1876, the French and British bondholders effectively ruled Egypt. The Europeans had not approved of the American presence from the beginning, and it was the European controlled Commission of Inquiry that officially terminated the employment of the few remaining American officers in 1878 . 
After almost ten years of concentrated effort, the American officers left the Egyptian army in virtually the same condition as they had found it. The refortifications, roads, canals, and light houses remained in Egypt, the Sudan, and Ethiopia as the only testament to the American presence. As technicians the Americans performed creditably, but as military advisors they left much to be desired. 
THE AMERICAN EFFORTS TO MODERNIZE THE EGYPTIAN ARMY UNDER KHEDIVE ISMAIL

by

ROBIN JOY LOVE BUXTON

A thesis submitted in partial fulfillment of the requirements for the degree of

MASTER OF ARTS

in

HISTORY

Portland State University

1979 
TO THE OFFICE OF GRADUATE STUDIES AND RESEARCH:

The members of the Committee approve the thesis of

Robin Joy Love Buxton presented December 7, 1978.

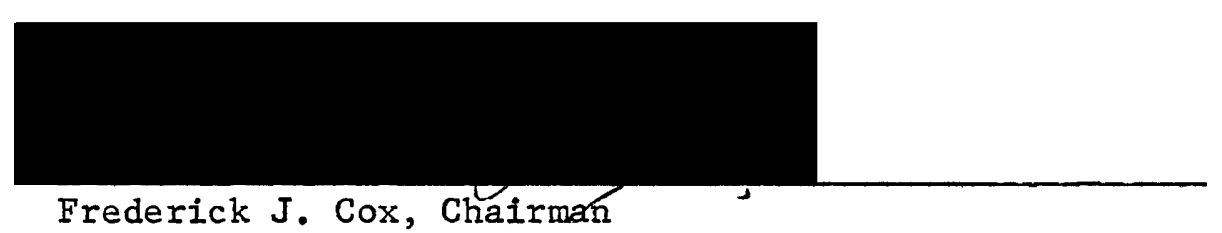

Frederick J. Cox, Chairman

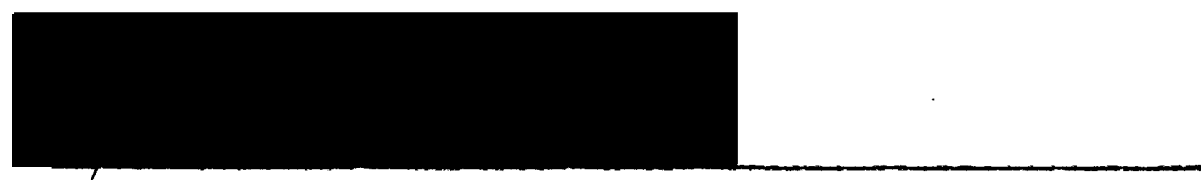

Ann Bennett

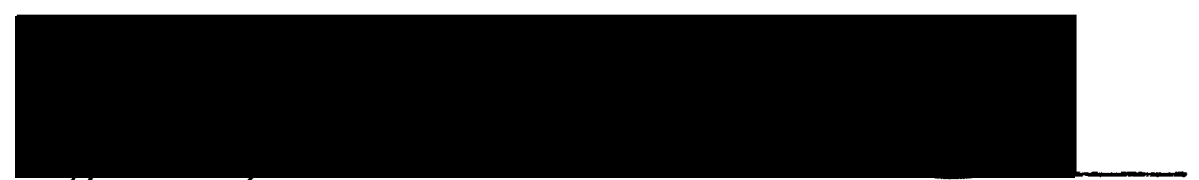

Gforge A./Carbone

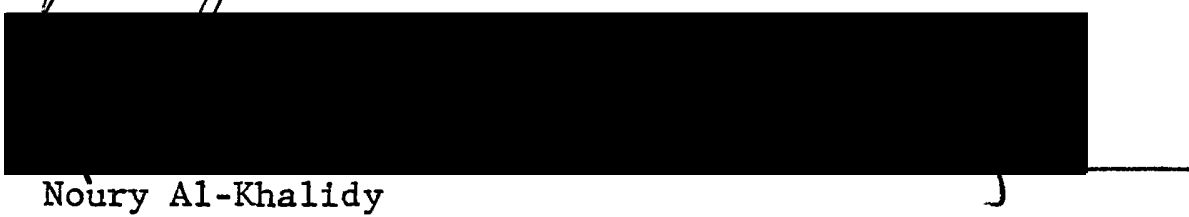

APPROVED:

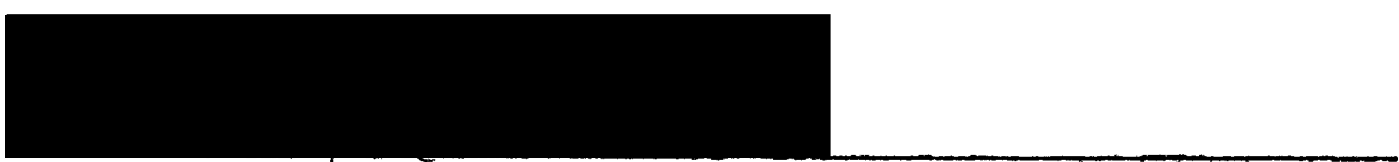

Michael F. Reardon, Head, Department of History

Stanley E. Rouch, Dean of Graduate Studies and Research 


\section{ACKNOWLEDGEMENTS}

I am very grateful to Dr. Frederick J. Cox for his encouragement, criticism, and patience throughout the numerous drafts of this paper. Without the unlimited use of his private notes taken from the Abdin Archives in Cairo and the free use of his private library, it would have been virtually impossible to research this topic without extensive travel. I now share his enthusiasm for the topic and like Dr. Cox, I hope that the personal papers of General Charles P. Stone will someday be rediscovered in someone's attic. At that time much of the speculation concerning the American presence in Egypt will, at last, be replaced by documented fact.

I wish to thank Robert Hunter for his insights into nineteenth century Egyptian history. When the contemporary written sources were sparce or contradictory, his specialized knowledge of the Egyptian politics and society of the time helped me to judge the reliability and value of the sources in question. In addition, I wish to express my appreciation to Dr. George Carbone, Dr. Basil Dmytryshyn, and Dr. Noury Al-Khalidy for their comments and criticisms on various drafts of this thesis. 
TABLE OF CONTENTS

PAGE

ACKNOWLEDGMENTS .................... . . . LIST OF MAPS........................ . . . . . CHAPTER

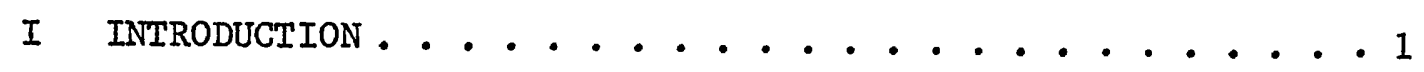

II KHEDIVE ISMAIL'S PLANS .............. 6

III ENTER THE AMERICANS . . . . . . . . . . . 24

IV THE CONFLICT BETWEEN THE PASHAS AND THE AMERICANS . . . . 60

$\mathrm{V}$ THE ULTIMATE DEFEAT. . . . . . . . . . . 84

VI CONCLUSION . . . . . . . . . . . . . . 124

BIBLIOGRAPHY . . . . . . . . . . . . . . . . 129

APPENDIX . . . . . . . . . . . . . . . . . 140 


\section{LIST OF MAPS}

MAP

PAGE

1. Le Soudan sous le Regne du Khedive Ismail . . . . . . . . 5

2. Chemin de Fer du Soudan (Projet Fowler) . . . . . . . 52

3. Massawa et le Samhar . . . . . . . . . . . 100 


\section{CHAPTER I}

\section{INTRODUCTION}

The continuing development of a superior military technology has played a significant role throughout the two-hundred-year history of the United States. Equally significant to world history has been the American efforts to share this technology with other nations. As a result, American military technology has often played an interesting and important, if not always a productive role in the modernization processes of developing countries throughout the world. The purpose of this paper is to describe and analyze one such attempt to share this "Yankee ingenuity" with another nation during the nineteenth century. Between 1869 and 1878 Khedive Ismail, the ambitious ruler of Egypt, employed approximately fifty American military officers to modernize his army. As graduates, for the most part, of the United States' military academies these men had received a highly technical education and as participants in the recent Civil War, they had been forced to apply their knowledge. The shrewd Khedive hoped to utilize this education and experience within Egypt. This relatively unknown story of the American efforts to reorganize and modernize the Egyptian forces without the sponsorship of the United States government comes as a striking contrast to 
the increasingly imperialistic policies of nineteenth century Europe. The following chapters are a reconstruction of the events that led to the formation of an unofficial, American mission through its ultimate dismissal almost ten years later.

Two related factors emerge from the available historical material of the time period to help explain the American-Egyptian relationship during the third quarter of the nineteenth century. The first and most fundamental factor was the multi-faceted role of the Khedive himself. Ismail was a man of unusually expansive vision and in his early career he realized that a modern and efficient army would help him implement some of his more ambitious dreams. When he brought the Americans to Egypt to reorganize and revitalize his armed forces, Ismail guaranteed his full support of the American officers' policies even when they came in direct conflict with Egyptian military prerogatives and/or traditions. However, Ismail was an absolute potentate in the best oriental fashion: Could he really afford such unconditional support for policies that were bound to antagonize his traditional allies, the Circassian and Turkish military officers?

The answer to that question lay beyond Ismail's personal control. From the beginning of the Khedive's military adventures, the European bankers, with their growing interests in Egypt, were suspicious of the Khedive's plans. Did he intend to break away from the Ottoman empire: Was he planning his own African empire? Or, would he even go so far as to liberate the Suez Canal from European control if the 
opportunity presented itself? None of these options were acceptable from the European point of view. Moreover, Ismail could not have afforded to underwrite his dreams even if the governments of Europe had allowed such grandiose plans to materialize.

Egypt in the late nineteenth century, due to Ismail's modernization programs and his lavish lifestyle, was fast falling into the last stages of bankruptcy to Europe. Consequently the British and French bondholders along with their respective governments did not approve of the Khedive's new and costly military enterprises. It is not surprizing to find that the American officers were among the first employees of the Egyptian government to be dismissed when the British and French Commission of Inquiry began its fiscal reforms in an effort to save Egypt from bankruptcy. Under such circumstances, Ismail needed all of the internal strength he could muster to maintain his position as Khedive of Egypt. When the final crisis came, Ismail had to rely upon his pashas as his only means of support and dismiss his American officers.

The second important element in this Egyptian/American relationship is the role of the American officers who agreed to go to Egypt with the goal of modernizing the Egyptian army. Modernization is a rather nebulous term and the Americans were to find that their assigned duties were often vague and open to various interpretations. Those placed within the technical sphere such as engineering projects or exploration and mapping expeditions were usually quite successful. Those men assigned to organizational or staff duties found their modernization efforts con- 
tinually thwarted by the traditional forces of the Egyptian government and society. When the American officers were called upon to use their own judgment on many sensitive, cultural issues, their bullheaded selfassurance often got in the way of any solution.

An understanding of the religious and social mores of this Islamic country, as well as a sensitivity to the status quo within traditional Egyptian society was needed to fathom the often obscure responses and outright opposition the American officers encountered. Fresh from their experiences in the Civil War, the American officers were among the finest military technicians available; unfortunately, as human relations specialists, they left much to be desired. But because of the ambitions of the Egyptian Khedive, Americans participated in an episode of Egyptian history for almost a decade of the nineteenth century in attempting to transform a traditional Egyptian society through modern technologies. 


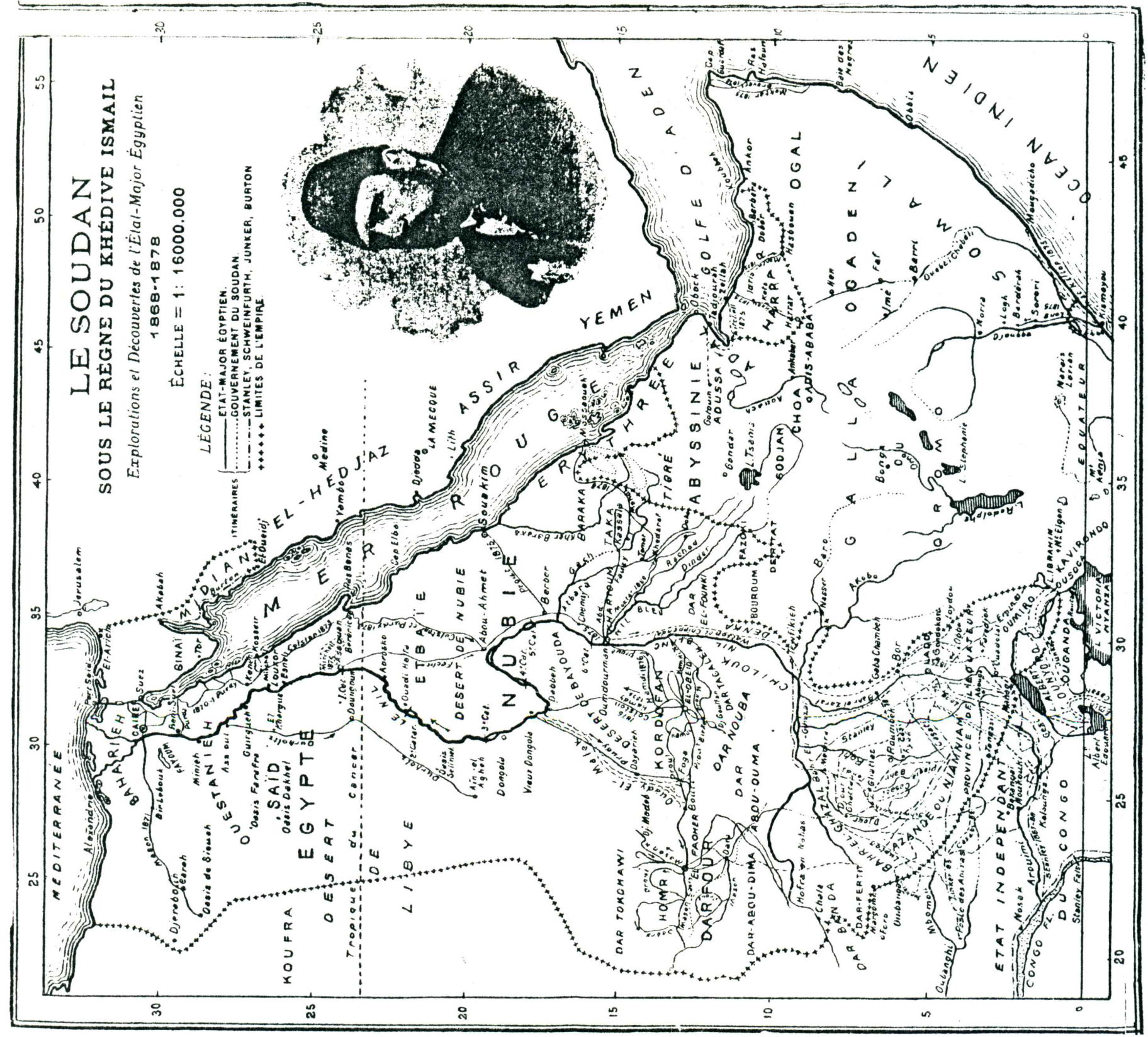

M. Sabry, L'Empire Égyptien sous Ismail et L'Ingérence Ang10Francaise, frontpiece. 


\section{CHAPTER II}

\section{KHEDIVE ISMAII'S PLANS}

By the second half of the nineteenth century, Egypt remained an Ottoman province more in name than in reality. In 1517 Selim I had conquered Egypt and established Ottoman rule over the local Mamluk dynasty. However, as the Ottoman empire declined in Balkan Europe and the Middle East over the following three hundred years, so diminished her control over Egypt. Napoleon Bonaparte's invasion of Egypt in 1798 and subsequent occupation to 1801 further demonstrated the weakness of Ottoman authority in the province. This brief interlude was followed by the rise to power in 1806 of Muhammad Ali, a Macedonian soldier who had been sent with the Ottoman forcés to rescue Egypt from the French grip. Under his leadership, the stagnating Egyptian economy was revived and the traditional Mamluk infrastructure of the government was destroyed. ${ }^{1}$ This allowed Muhammad Ali the leverage

$1_{\text {Although the Ottomans gave Egypt the formal administration of a }}$ province with a Turkish governor, a military garrison, and an official tax collextor, the remnants of the medieval Mamluk military households retained much of their previous power and influence. As the Ottoman authority declined, the Mamluk families proliferated, their power with them. They were appointed governors of local provinces and they were named commanders of special expeditionary forces outside of Egypt. They 
required to further loosen the formal ties between the Sublime Porte and its Egyptian province.

In addition to these changes, Muhammad Ali reorganized the Egyptian military system with the aid of his son Ibrahim and numerous European military advisors, thus creating the means for carving out an Egyptian empire within the confines of the weakening Ottoman empire. Although Muhammad Ali's primary imperial ambitions were directed towards the four Ottoman pashaliks (governorships) in the Levant, his first campaigns were fought to gain recognition as an emerging power within the Ottoman empire. ${ }^{2}$ His initial campaign for the control of Mecca and Medina (the two holiest cities of Islam) was designed to please the Ottoman Sultan Mahmud and to help him rid himself of his more rebellious troops through attrition. ${ }^{3}$ As a result of these campaigns he needed to replenish both his military ranks and his government's coffers. His 1820 campaign to the Sudan appeared to be a solution to both needs.

even appropriated the positions of commander of the treasury convoys to Istanbul. Nevertheless, by 1798 the medieval Mamluk domination of the equally backward Ottoman administration in Egypt meant little when compared to the powers of the rapidly industrializing countries of Western Europe.

Encyclopedia of Islam, 1937 ed., s.v. "Muhammad Ali."

3 Henry Dodwe 11, The Founder of Modern Egypt (Cambridge: Cambridge University Press, 1931), p. 45. 
The two-fold objectives of the Sudanese campaign were the acquisition of manpower and appropriation of natural resources. 4 Muhamad Ali intended to conscript the Sudanese men for service in his army. Those not forced into military service often found themselves in the domestic slavery system of Egypt, a dubious reprieve at best. In addition to its manpower the Sudan appeared to offer numerous commercial opportunities. There were scattered rumors suggesting the existence of large gold mines, not to mention other valuable resources such as cattle, ivory, and gum arabic. ${ }^{5}$ Muhamad Ali hoped to tap these riches to help facilitate his imperial ambitions elsewhere. The objectives of his Sudanese venture were never fully met. The Sudanese conscripts proved highly susceptable to Egyptian diseases

${ }^{4}$ On a more speculative level, there may have been a third objective in Muhamad Ali's Sudanese venture. Since pharonic times the theory that the unity of the Nile valley was necessary for the survival of any power in Egypt had existed. Because the sole Egyptian water supply and consequently the lifeline of the Nile basin was this tremendous river, any interference with the Nile's sources would-be fatal to Egypt's very existence. Whether or not the technology to divert any part of the Nile existed among the tribes of central Abyssinia and the Sudan is questionable; however, the belief had permeated the minds of Egyptian rulers for centuries and even contemporary Europeans spoke of the possibility. Sir Samul Baker, a reknowned explorer and one time Governor-General of the Sudan, believed that the Biblical seven-year famine could be explained by a diversion of the Nile. He eventually used his argument to help convince the British of the importance of the Sudan in relation to their maintenance of Egypt in the late $1880^{\prime} \mathrm{s}$. This theory is fully discussed in William L. Langer, The Dipolmacy of Imperialism (New York: Alfred A. Knopf, 1951), pp. 103-5.

5 John Marlowe, Spoiling the Egyptians (New York: St. Martins Press, 1975), p. 128 . 
and they died in large numbers. ${ }^{6}$ The few gold mines discovered were void of the valuable mineral in any quantity. However, a substantial domestic slave trade did develop and some trade in ivory, feathers, and gum arabic was established.

In spite of the minimal success of the campaign, Muhammad Ali did not abandon his new possessions. Under the 1841 settlement forced upon him by the European powers after his second Syrian campaign, he received title for life to the lands of Nubia, Darfur, Kordofan, and Sennar as partial compensation for the land and concessions he had been forced to relinquish in the Levant. ${ }^{7}$ In the 1846 settlement, Muhammad Ali received the lease for the ports of Suakin and Massawa on the Red Sea. However, this lease was not renegotiated by his successor Abbas, so the ports were returned to Ottoman suzerainty in 1849. 8 Thus, Muhammad Ali's efforts to acquire a foothold in the African interior came to a conclusion.

Due to the strength of his military machine, Muhammad Ali's legacy to his successors was a virtually autonomous Egyptian empire within the boundaries of the decaying Ottoman empire. Although Muhammad Ali's

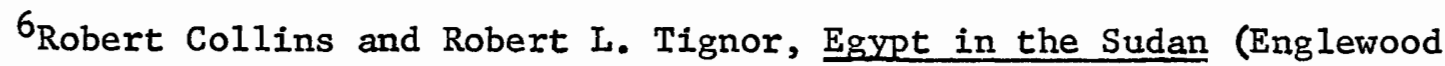
Cliffs, N.J.: Prentice Hall, Inc., 1967), p. 55.

${ }^{7}$ M. Sabry, I'Empire Egyptien sous Ismail et L'Ingerence Ang10Francois (Paris: Librairie Orientaliste Paul Geuthner, 1933), p. 384. 8Marlowe, p. 128. 
reign spanned thirty five years, the many changes he forced upon his army were never completely assimilated. His immediate successors, lulled by twenty years of peace, discontinued Muhammad Ali's modernization measures and the Egyptian forces soon reverted to their previous ineffective condition. Thus when Ismail came to power in 1863 he inherited this legacy of Egyptian autonomy and a backward army of little military use. Nevertheless, as second son of the great Egyptian general Ibrahim Pasha and grandson of the dynamic Muhammad Ali, Ismail exhibited the same qualities of ambition and vision so markedly demonstrated by his forebearers.

Unlike his illustrious father and grandfather, however, Ismail possessed a westernized education and an unabashed admiration for European culture and technology. In this respect Ismail differed from Muhamad Ali who had through experience developed a healthy skepticism for the many "benefits" of European civilization. It was this crucial difference that set the character of Ismail's reign in Egypt. In order to understand the American mission's role in Egypt it is necessary to first delve deeper into the circumstances surrounding the Khedive, himself.

In spite of his European habits and liberal opinions, Ismail spent only two years of his education in Europe. He attended the private palace school of the royal family in Egypt during his early years studying Arabic, Persian, and Turkish along with the traditional pri- 
mary subjects. 9 Not until the age of sixteen did he leave for Paris to further his studies. There he attended an Egyptian educational mission where he perfected his French and studied some modern sciences and engineering. 10 Ismail returned to Egypt in 1848 to take his place amidst the uncertain atmosphere of dynastic politics steming from his father's and grandfather's death within a year of each other. During the years between his return from France in 1848 and his accession to the throne in 1863, Ismail maintained a low profile in public 1ife. Due to the traditional Ottoman suspicion among heirs to the throne, Ismail was forced to live in Constantinople for the reign of his cousin, Abbas, from 1849-1854. While residing in the Ottoman capital, Ismail served Sultan Abdul Mejid as a member of the State Judicial Council. He returned to Egypt with the accession of his uncle Said Pasha in 1854. Although Ismail spent most of the eight year reign of Said Pasha successfully managing his private estates, he did serve in an official capacity for his uncle when needed. In 1855, Ismail was sent on a diplomatic mission to the court of Napoleon and in 1861, Said Pasha appointed him Sirdar (Commander in Chief of the Army) during

${ }^{9}$ In spite of the military tradition in his family, Ismail did not receive a military education. General Charles P. Stone, Ismail's Chief of Staff, reports that as a child Ismail was present at his father's second Syrian campaign. If he did accompany Ibrahim Pasha, the observations of a nine-year-old boy are the closest Ismail seems to have come to a military education.

${ }^{10}$ Encyclopedia of Islam, New Edition, s.v. "Ismail Pasha," by P. J. Vatikiotus. 
11

a Sudanese rebellion. Thus when Ismail came to the throne upon the death of Said Pasha, on January 18, 1863, his future appeared uncommonly bright. He had proven himself an efficient administrator with diplomatic and military service, and his Europeanized education had provided the new ruler with at least the facade of a liberal ruler in a modern age. While Ismail's educational background may have differed substantially from his grandfather's, his ambitions were certainly as extensive. He had inherited a reasonably concrete claim by historical and imperial standards to the vast territories of central Africa. Like his grandfather, Ismail had numerous reasons of his own for re-establishing possession of this African territory. In his employ was a Swiss adventurer named Werner Munzinger who began writing memoranda as early as 1855 extolling the virtues of the Sudan. ${ }^{12}$ The merits of Munzinger's ideas may have grown proportionately more advantageous as Ismail's financial situation grew more desparate.

In his "Observations sur 1a. Situation Economique du Soudan" written in 1871, Munzinger wrote enthusiastically on all aspects of the Sudan. The rich soil, sprawling plains and plateaus, and sufficient rains were surely meant to support large cotton fields. The

${ }^{11}$ Encyclopedia of Islam, New Edition, s.v. "Ismail Pasha," Ismail's service as Sirdar was titular only, and while it may have given him some understanding of the military administration in Cairo, it should not be mistaken as substantial military experience.

12 Frederick J. Cox, "Munzinger's Observations on the Sudan, 1871," Sudan Notes and Records 33(1952), p. 189. Munzinger lived twenty years along the Red Sea coast serving the British, French, and finally the 
commercial possibilities were infinite. He claimed that one would discover abundant cattle, gum, hides, ghee and ostrich feathers,..timber, ivory, and gold as we11. ${ }^{13}$ The envisioned potential of the Sudan had inflated tremendously since Muhammad Ali's time. However, Munzinger went further in his scenarios. He suggested plans for railroads, sanitary measures, public works, and education to transform the Sudan into an integral and profitable part of Egypt. ${ }^{14}$ Ismail, who was a dreamer and an imperial gambler at heart, could not help but be intrigued by such a sweeping vision. Impressed as he may have been by Werner Munzinger's advocacy of an Egyptian-Sudanese empire, there were other factors to be considered. How would the governments of Europe view these plans?

The Middle East political scene during the entire nineteenth century was orchestrated by the major governments of Europe. Ismail knew this well from both his observations of his grandfather's difficulties dealing with the Europeans and through his own experience with them. In case prior dynastic claims and commercial reasons might prove insufficient justification for a large-scaled Egyptian occupation of the Sudan and possibly central Africa, Ismail prepared a third and

Khedive in different diplomatic, military, and commercial capacities. According to American opinion, Munzinger was an opportunist of the first order, and not above carving his own personal empire out of area. (Lockett papers.)

$$
\begin{aligned}
& { }^{13} \text { Ibid., pp. 193-195. } \\
& { }^{14} \text { Ibid., p. } 200 .
\end{aligned}
$$


compelling reason for his actions to convince the European powers not to interfere with his plans. The Sudan and surrounding areas were the central marketing place of the thriving African slave trade. 15 Ismail proposed to halt this rapacious and inhumane commerce under his rule. Without debating the sincerity of his motives, a highly controversial subject, he certainly recognized the effect that such a program would have on the British. The anti-slavery movement was strong in Great Britain at that time, and Ismail was able to secure initial British acceptance of his plans with this stance. He reinforced his intentions by engaging Sir Samuel Baker, a competent and energetic Englishman, as his Governor-General charged with the task of destroying the slave trade and organizing the territory. ${ }^{16}$ with this action Ismail prevented any immediate reaction in Europe; however, this did not eliminate all of the obstacles in his way.

As ruler of the Ottoman province of Egypt, Ismail was still answerable to the Sultan. He had, however, found the path to Ottoman acquiescence through financial renumeration. Ismail and his agents were able to successfully bribe those Ottoman officials needed to secure a large number of favorable firmans (royal proclamation with

${ }^{15}$ Georges Douin, Histoire du Règne du Khédive Ismaï1, Tome III, $1^{\text {re }}$ Partie (Rome: Societe Royale de Geographie d'Egypte, 1936), p. 478. 16 Ibid. 
the force of law) from Sultan Abdul Aziz. These firmans dealt with a variety of Ottoman concessions in areas of hereditary rights, financial obligations, treaty negotiating privileges, and most importantly for his imperial ambitions, the size of the Egyptian military establishment. If Ismail intended to invade and occupy such a large territory as the Sudan and perhaps extend his sovereignty as far south as Uganda, he would need a substantial and well-organized army similar to Muhammad Ali's. When he came to the throne, Ismail found the Egyptian forces in complete disarray. The size of the army had been 1 imited to 18,000 men by the 1841 convention that Muhammad Ali had been obliged to accept. ${ }^{17}$ However, the army had seldom reached that strength after Muhammad Ali's death. On his accession, Said Pasha had found the army reasonably well equipped but he allowed and even encouraged lax disciplinary standards that eventually destroyed the army as a functioning force. 18 In addition, he reduced the size of the military by $8,000-10,000$ men in order to fill

${ }^{17} \mathrm{~J}$. Carlisle McCoan, Egypt As It Is (London: Casse11 Petter \& Galpin, 1877), p. 99.

${ }^{18} \mathrm{~J}$. Heyworth-Dunne, An Introduction to the History of Education in Modern Egypt (London: Luzac \& Co., 1938), p. 314. Said Pasha had a tendency to promote Egyptian officers to high ranks, often at the expence of their Turkish and Circassian counterparts. While this gave new opportunities to native Egyptians, they were not always properly trained for the job and this preference of Said's offended his Circas-. sian and Turkish allies within the military organization. 
the corvee labor ranks working on the Suez Canal. ${ }^{19}$ This obviously had a debilitating effect upon what remained of the Muhammad Ali military organization.

In short, the army that Ismail inherited in 1863 had reverted to the traditional Ottoman military organization that Muhammad Ali had tried to eliminate. The "pasha system" not only survived but was revived during the years following Muhamad Ali's death. 20 The system was coordinated from the throne in the; person of the Minister of War. All orders to the army were directed by the Minister of War and his seal was required before any action could or would be taken by his subordinates. In turn, with few exceptions, the entire army sent its military documents to the Minister of War. ${ }^{21}$ The inefficiency that this kind of absolute authority produced bordered on incredulity. For example, the Minister of War often insisted on inspecting a11 of the new recruits himself. ${ }^{22}$ The men would be sent to his office in

${ }^{19}$ Ibid. When Said Pasha granted the Suez Canal concession to Ferdinand delesseps, he not only agreed to pay for nearly half of the enterprise, he also agreed to supply the labor force free of charge and to give large portions of land along side of the Canal to the company. It was an expensive proposition for Egypt.

20 The phrase "pasha system" as it is used throughout this paper refers to the traditional Ottoman military organization whereby each individual commander functioned as an independent unit directly responsible to the Minister of War.

${ }^{21}$ William W. Loring, A Confederate Soldier in Egypt (New York: Dodd, Mead \& Co., 1884), p. 357.

${ }^{22}$ William McE. Dye, Moslem Egypt and Christian Abyssinia. (New York: Atkins and Prout, 1880; reprint ed., New York: Negro Universities Press, 1969), p. 170. 
the Citadel in Cairo to wait for his nod of approval and often, they would have to return daily for weeks before the Minister would have the time to give his assent.

Obviously the Minister could not attend to every military document that arrived at his office. Rather than appoint an official subordinate to fill some of his duties, the Minister of War preferred to assign the work to his office staff. In this way he protected at least the nominal authority of his office. Thus the office personnel, especially those authorized to wield the Minister of War's seal, occupied a position of considerable authority. These civilian clerks, usually Copts, recognized the advantages of their position, and they worked steadily to increase their influence. 23 Among the advantages of a position in the Ministry of War was the baksheesh (bribes) for drawing the Minister of War's attention to a specific project. In such a system, where all activity depended upon the pronouncement of essentially one official, efficiency and speed were at a minimum.

Reporting to the Minister of War were the individual pashas, generally Circassian and Turkish generals. These men were part of a traditional military caste from which the Muhammad Ali dynasty drew its strength and allies. These men were not only the military chiefs of their divisions or battalions but they filled the positions of quartermaster, commissary officer, paymaster, and transportation

23The Copts had a strong tradition of education in the largely illiterate society of the time. Hence, they generally served in the administrative positions of government in Egypt as clerks and scribes. 
officer as we11. ${ }^{24}$ In peace-time the pasha might have such administrative duties as customs collector or tax farmer in addition to his military duties. 25 The pashas, in effect, maintained absolute control of the logistical requirements of their own battalions. Any outside interference by a general staff would have been considered trespassing upon their traditional prerogatives and a gross impropriety. Like the Minister of War, the pashas were jealous of their powers and the ubiquitous Coptic clerk in the service of the pasha could be found commanding the similar status as his counterpart in the Minister of War's office.

The power of the clerk depended upon the personality and ambition of his pasha. If the colonel or general was illiterate, indolent, or weak, a cunning clerk could control the battalion or division with his own interests in mind. If on the other hand, the pasha were a responsible leader of the troops, the clerk could serve as his calculating right hand. With a satisfactory relationship established between them, the military orders of the command were eventually carried out, although not in a particularly efficient or accountable manner. ${ }^{26}$

${ }^{24}$ George B. McClellen, "A Winter on the Nile," Scribner's Monthly 13 (January, 1877), p. 373.

$$
\begin{aligned}
& { }^{25} \text { Dye, p. } 71 . \\
& { }^{26} \text { Dye, p. } 169 .
\end{aligned}
$$


At the bottom rung of this hierarchy was the conscripted Egyptian peasant, the fellah. All Egyptians were liable for conscription excepting the residents of Cairo and Alexandria; who were exempted from the military draft by virtue of a chartered privilege. Two consequences of this policy are apparent. Most noticeably, the Egyptian army could include Muslims, Christians, and Jews alike. This was a striking contrast from traditional Ottoman policy which generally limited the Turkish army to Muslims alone. The second consequence was particularly unfortunate in that the agricultural worker, the fellah, was the primary subject of the draft. The countryside was often stripped of its most valuable labor source and Egyptian agriculture suffered for this policy. 27

It was also possible to buy one's exemption from conscription. The sheikhs and mudirs called upon to supply the draftees would accept a bribe in place of a particular body. They merely called up one more fellah who could not pay the price. ${ }^{28}$ There was no age limit for service and the term of conscription was usually life unless one could afford to buy a shortened term. Military service was so unpopular that it was common to see the new "recruits" brought to

$$
\begin{aligned}
& 27 \text { McCoan, p. } 101 . \\
& { }^{28} \text { Dye, p. } 56 .
\end{aligned}
$$


camp chained together in pairs and self-mutilation was fairly common. 29 Consequently the Egyptian army was filled with soldiers forcibly conscripted, and lacking any incentive to do more than the bare minimum of their assigned duties. Such an army was not ready to serve within Egyptian boundaries much less conquer an empire.

The final obstacle in the way of Khedive Ismail's imperial dreams was Egypt's financial situation. On his accession in 1863 Ismail inherited a tremendous public debt that amounted to approximately $€ 3,293,000$, an enormous commitment in the way of manpower and land rights to the Suez Canal project, and a close relationship with France. 30 The debt, though not of his making, was legal and binding. The Suez Canal situation, however, was intolerable and Ismail intended to seek amelioration and reparation by renegotiating the Suez contract and he decided that his close relationship with France would be the key to success. Within two months of his accession, Ismail requested a review of the contract signed by his predecessor. He asserted that the large amounts of land ceded to the Canal Company were a violation of his sovereignty and he objected to the corvee labor provided free of charge as inhumane and tantamount to slavery. Ismail allowed the dispute to

${ }^{29}$ Raleigh E. Colston, "Modern Egypt and Its People," Journal of the American Geographical Society of New York 19(1887), p. 143.

30 Earl of Cromer, Modern Egypt, vol. 1 (New York: The MacMillan Co., 1908), p. 11 . 
go to arbitration with his "special" friend, Napoleon III of France, as the judge. On January 30 , 1866, Ismail learned what price his special friendship had cost. The stunning sum of 84 million francs had been accessed for Ismail's efforts. 31 The Suez Canal settlement was only the first financial defeat dealt by the European bondholders to Ismail; many more were to come.

The leftover public debt and the expensive Suez Canal settlement might have bankrupted the Egyptian treasury early in Ismail's reign had it not been for the American Civil War. The Union blockade of the Confederate states meant the Egyptian long-fibered cotton was the only quality cotton on the international market. The dramatic rise in the price of cotton saved Egypt from immediate financial embarrassment. In fact, income from this windfall allowed Ismail to invest in more and varied projects thus creating even more debts to be paid at a later date. Unfortunately for the financial situation in Egypt, the Civil War in America ended in 1865. Once the war was over, American cotton once again flooded the world market, and the previously inflated price of cotton dropped quickly leaving Ismail perilously close to financial disaster. However, the day of reckoning was still a long way off, for Ismail hoped to find a way out of his financial difficulties.

${ }^{31}$ Douin, Tome Premier, pp. 194-98. 
While Ismail's confidence in himself was unfailing, the European governments' confidence in Ismail was waning, and they watched all of his projects closely with growing consternation. The British were particularly distressed over the rumors in 1869 that Ismail was secretly purchasing large quantities of Remington rifles and other armaments from the United States. ${ }^{32}$ These speculations were followed by more rumors that Ismail had hired tweIve American officers to revamp and revitalize his army. 33 The French were equally apprehensive, partially because the French military mission led by Colonel Mircher which had been sent to Egypt in 1864 on the request of Ismail had been recalled to France in $1869 .{ }^{34}$ Upon the arrival of the American officers in Egypt, the French Government objected to their employment. Ismail is said to have replied that the French officers had been under the orders of the French Minister of War; the American officers would be under

${ }^{32}$ Public Record Office, F.0. Archives, 65/800, St. Petersburg, January 12, 1870. Buchanon to Clarendon, No. 14; and, Public Record Office, F.0. Archives, 27/1802, May 13, 1870. Lyons to Clarendon, No. 463. (As taken from the personal notes of Dr. Frederick J. Cox).

33Public Record Office, F.O. Archives, 5/1192, April 25, 1870. Thornton to Clarendon, No. 168; and Public Record Office, F.O. Archives, 27/1802, May 13, 1870. Iyons to Clarendon, No. 462. (As taken from the personal notes of Dr. Frederick J. Cox).

${ }^{34}$ Sabry, p. 385. The French officers were recalied by the French Minister of War in response to the impending Franco-Prussian War of 1870. Colonel Chaille-Long implies, in one of his articles, that the French departure specifically triggered the employment of the American officers. Charles Chaille-Long, "Princes of Egypt", Cosmopolitan 21(January, 1899), p. 260. 
his orders. ${ }^{35}$ Ismail's response did not alleviate French concerns about his ambitions at all.

In spite of the British and French protestations, Ismail did employ a number of American officers to help reorganize his army. Their arrival in Egypt and their subsequent assignments were a matter of great interest and concern to the European observers. The Khedive's motives and plans for the future were not readily apparent in early 1870. Would Ismail follow in Muhammad Ali's footsteps and threaten the European control over the Ottoman empire? The British and French governments could only wait and watch for the effects of the new American presence for the moment.

35 Public Record Office, F.0. Archives, 78/2139, February 4, 1870. Stanton to Clarendon, No. 20. (As taken from the personal notes of Mr. Robert Hunter.) 


\section{CHAPTER III}

\section{ENTER THE AMERICANS}

Although Ismail's decision to hire a number of American officers to train his army must have startled many of the Khedive's European observers, this action did not materialize entirely without warning. The United States had come to Ismail's attention early in his reign. It had been the American Civil War that caused the sharp rise in the price of Egyptian cotton and the consequent increase in Egyptian prosperity. On a less cordial note, Ismail experienced American displeasure in the form of consular appeals when he dispatched a contingent of Sudanese soldiers to aid the French efforts to place Maxmillian, the Archduke of Austria, on the throne in Mexico. 1 In both cases, the growing military proficiency of that far off nation was amply demonstrated, and even Ismail, with his scant knowledge of military affairs, watched the American progress. ${ }^{2}$

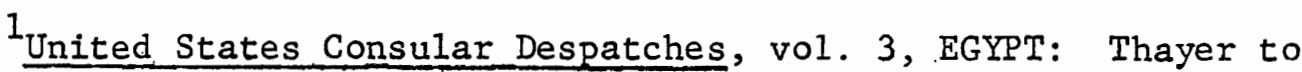
Seward, desp. 26-29, January 9-February 3, 1863.

2 United States Consular Despatches, vol. 3, EGYPT: Thayer to Seward, desp. 113, November 13, 1863.

Ismail watched the American Civil War from a distance, discussing the latest events with Consul General Thayer. He offered to sell arms and ammunition to the United States and he authorized the closure of Egyptian ports to any Confederate ships that found their way to the eastern Mediterranean. 
There were three excellent reasons for selecting American officers as opposed to officers from Great Britain or from another European country. To begin with the American military men had just fought in a war with the most technologically advanced weapons ever devised. Such experience and expertise would be an invaluable asset when training a newly reorganized and inexperienced army. Secondly, the Americans and their government did not have the financial ties with Egypt that the European countries possessed. Furthermore, Ismail may have sensed a growing influence on the part of the United States in the world. He had watched the Americans intimidate Napoleon III of France to the point that the emperor withdrew the French troops from Mexico leaving the 111 -fated Archduke Maxmillian to his ultimate defeat. This kind of military influence used for political purposes fit in well with Ismail's future plans. The final reason for looking towards the United States for military aid involved the willingness on the part of ex-Confederate and Union army and naval officers to work in Egypt on Ismail's terms. These men would be subject to the Khedive's orders, not the American Secretary of War or the American Consul-General in Cairo.

The Americans' willingness to travel such a great distance to a foreign country to serve as mercenaries stemmed from a variety of circumstances mostly due to their roles in the recently concluded Civil War. Those men who had fought valiantly for the Confederate cause found themselves barred from further military service in the armed forces of the United States. In addition, most of their personal 
wealth had disappeared along with their cause. Some of the officers had been fortunate enough to find position as instructors in a number of small southern colleges. However, most of the former Confederate officers were in immediate need of employment. Whatever their personal situations may have been, life during the reconstruction era in the South was often unbearable for the proud ex-military men. Consequently, most of the southerners were pleased to be back at work in their chosen profession and some were distinctly relieved to have left the American shores behind. ${ }^{3}$

Despite their service on the victorious side in the war, many of the Union military officers were in the same position as their southern counterparts. A number of the officers had only a mediocre military record to show for their wartime service and a career in the armed forces was unlikely. Even those men with reasonably sound records had poor prospects because after the war the funds for the military forces were drastically reduced. Those allowed to continue were faced with the dismal prospect of chasing Indians without the

\footnotetext{
$3_{\text {Henry Derrick Letters, 1875-1878, in private possession, Derrick }}$ to Derrick, July 26, 1875.

Derrick, aboard the steamer "Spain," writes to his wife "What a relief to be rid-of that horrid rag called the stars and stripes which floats over so much corruption and tyranny clad in the garb of Liberty, and whose praises have been sung, ad nauseam, by so many blind patriots! I must confess my spirits rose and my heart beat freely as if relieved from the weight of some great incubus which has rested in it ever since the great surrender at Appomattox, C. H. fell like a ball upon the lifeless South."
} 
necessary financial support from Washington. The future of the American army officer was discouraging, and it was not surprising that some of the officers accepted the opportunity to serve elsewhere. 4 Thus Ismail's search for military help came at a propitious time for most of the men and the American officers were enthusiastic and ready to serve the Khedive.

Just how and when Ismail came upon the idea of actually employing American officers is still a matter for speculation. Since Egypt was technically a vassal state of the Ottoman Empire, Ismail's official diplomatic contact with the United States was limited to the American Consul-General in Alexandria. The consular records show no evidence that he ever sought to arrange the employment of officers through that channe1. Instead, circumstantial evidence points to one man, Thaddeus Mott, an American, as both the instigator and the initial contact for Ismail's plans. They apparently met in Constantinople in 1868 on one of Ismail's financial lobbying excursions to the Sultan's capital. This was the year prior to the removal of the French military mission in Egypt. Mott, recently returned from service in the American Civil War, must have impressed the Khedive with his

${ }^{4}$ Annual Reports of the Association of Graduates (West Point, N.Y.: U. S. Military Academy, 1926), p. 182 .

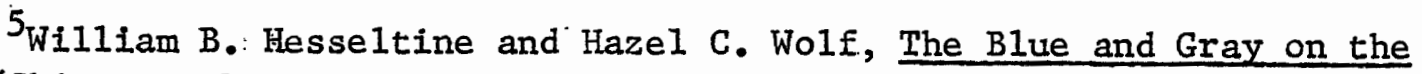
Nile (Chicago: : University of Chicago Press, 1961), p. 18. 
intimate knowledge of the recent conflict and his apparent competence as a military officer. It is likely the idea was born in Constantinople because it materialized soon after their meeting.

Thaddeus Mott was in a unique position to encourage such an enterprise. His father, Dr. Valentine Mott, a world reknowned surgeon, had operated on the Ottoman Sultan Abdul Mejid when in Constantinople in 1836 on one of his many excursions to Europe. ${ }^{6}$ Dr. Mott's successful removal of a tumor from the Sultan's brain gained the doctor and his family great favor in the Ottoman court. Thaddeus's sister married Blaque Bey the Ottoman envoy to Washington, D.C. further strengthening the Mott family ties to the Ottoman court. ${ }^{7}$. Thaddeus Mott went on to serve as an officer in the Union Army and he met a number of high ranking officers in the course of the war. Thus through his family connections with the Ottoman court, Mott gained the confidence of the Khedive; and through his military service, Mott was able to gain the confidence of the officers who would be proffered positions in the Egyptian army.

Whether or not Mott and Ismail discussed a plan for employing American army officers in 1868 in Constantinople has not been documented. However, by early Apri1, 1869, Mott arrived in Alexandria,

The National Cyclopedia of American Biography, fol. 6 (New York: James T.W. \& Company, 1896), pp. 281-283.

7 Hesseltine, p. 18 . 
8

Egypt. On September 24,1869 , he was appointed as Chamberlain to the Khedive with the rank of ferik (Major General). ${ }^{9}$ Within two months of that apppointment, Mott was on his way to the United States to hire former American military officers for the Khedival service.

The man who facilitated Mott's search for available officers was none other than General William T. Sherman, Commander-in-Chief of the United States Army. Certainly no man was in a better position to understand the difficulties faced by his former colleagues on both sides of the conflict, and his special interest in this project can be inferred from the fact that he eventually recommended the majority of the men employed by the Khedive. While his connection with the recruitment can be documented, the channels he used in the early years are somewhat obscure. ${ }^{10}$ One account states that General Sherman actually visited Egypt in 1869 and conferred directly with Ismail; however, the consular despatches do not verify this assertion. ${ }^{11}$ Further-

8 The United States Consular Despatches, vol. 5, EGYPT: Hale to Fish, desp. 152, April 14, 1869.

9 Pierre Crabites, Americans in the Egyptian Army (London: George Rutledge \& Sons, Ltd., 1933), p. 8.

${ }^{10}$ Virtually every officer who wrote about or left records of his experience in Egypt mentions General Sherman's role as an advisor and/or agent for the Khedive. In additions to these individual references Gen. Stone's correspondence with Gen. Sherman documents the time and energy Sherman spent in locating prospective officers for Egyptian service.

${ }^{11}$ James M. Morgan, Recollections of a Rebel Reefer (Boston: Houghton Mifflin Company, 1917), p. 266. 
more, the year of 1869 . was a very busy one for the General because he concluded his command of the Mississippi Division which spanned the entire Mid-West from Eastern Ohio to the Rockies and from Texas to Canada, in St. Louis and moved to Washington, D.C. to become the Commander-in-Chief of the Army at the request of newly elected President Grant. 12 It seems that General Sherman did not visit Egypt until early 1872 and by that time he was already fully involved recruiting the American officers. 13

Upon his arrival in the United States, Mott immediately set to work locating willing recruits for the Egyptian army. By December 17, less than three months from the day he had joined the Egyptian ranks himself, he had his first two contracts signed. 14 Two factors for his immediate success have been alluded to: the financial needs of the American military officers at the time and the Sherman connection which lent an air of respectability to the offers. A third factor of a more intangible nature should be mentioned. Mott told the first group of Americans to be employed (about twenty in number) that they would soon see military action: the Khedive was going to fight to

${ }^{12}$ Lloyd Lewis, Sherman: Fighting Prophet (New York: Harcourt Brace and Company, 1958), pp. 594-600; and James M. Merril1, William Tecumsah Sherman (Chicago: Rand McNally \& Company, 1971), pp. 328-342.

13 William T. Sherman Papers, vo1. 31, 1871-1872. Library of Congress Archives, Stone to Sherman, Cairo, January 27, 1872.

${ }^{14}$ Crabites, Americans, p. 8. 
Iift the oppressive Ottoman yoke from his country's back. ${ }^{15}$ The officers, knowing very little about the political realities of the situation, took Mott at his word. '. There is a certain idealistic tone to the memoirs of those men who went to Egypt to wrest her from the grips of tyranny. Perhaps this fervor embodied the same hopes and dreams of the vanquished southerners and the less than illustrious northerners transferred to a new cause. In any event, Mott quickly signed his first two recruits, General William Wing Loring and General Henry H. Sibley, both former officers in the confederate army. Mott returned with them to Egypt leaving his brother, Henry A. Mott, as his agent to negotiate future contracts. 17

The contract provisions were uniform, explicit, and reasonably generous. The men would receive pay equal to their counterparts of the same grade in the United States Army for the year 1869.18 The

${ }^{15}$ Charles Chaille-Long, "Princes of Egypt," Cosmopolitan 26 (January, 1899), P. 261.

${ }^{16}$ Morgan, p. 267. Captain Morgan reported that the Americans were anxious to get to Egypt for fear that they would miss the first confrontation. Upon arrival in Alexandria he was surprized to find no preparations for war anywhere.

${ }^{17}$ Charles Chaille-Long, My Life in Four Continents (London: Hutchinson and Company, 1912), p. 16.

18 William McE. Dye, Mos lem Egypt and Christian Abyssinia (New York: Atkins and Prout, 1880; reprint ed., New York: Negro Universities Press, 1969), p.2. 
contracts were for a five-year term and renewable if both parties agreed at the end of the term. In cases of illness, the officer could resign and receive two months severance pay plus travel expenses home, or he could take a leave of absence at half pay. When sent on expeditions or to war the officer would receive an additional onefifth of his pay and any additional expenses. Should he be dismissed, the officer would receive six months severance pay and a travel allowance home. In cases of death on the battlefield, pension terms for the family were also provided. In general the terms seemed quite sufficient to meet the needs of the American officers. ${ }^{19}$

In addition to the strictly "bread and butter" provisions of the contracts, there were a number of legal and political aspects that were important. For example, the officer agreed that he would "not under any event, be governed, controlled by or submit to any order, law, mandate or proclamation made or issued by the Government of the United States of America. . ." The officer agreed to "make, wage and vigorously prosecute any and all enemies. . " of the Khedive. However, should the enemy be the United States, the officers would not be held to that condition. ${ }^{20}$ A third clause waived "all claims

${ }^{19}$ The United States Consular Despatches, vol. 7, EGYPT: Beardsley to Fish, desp. 112, July 10, 1873 .

${ }^{20}$ Ibid. 
of protection usually afforded to Americans by Consular and Diplomatic agents of the United States." 21 In addition to giving up their claims to American diplomatic assistance, the officer agreed,

that all legal questions and disputes of every nature which may arise between the party of the second part (the officers) and citizens or natives of Egypt shall be adjudicated and disposed of by the tribunals of justice in Egypt, and that the Government of the United States and its Consul or consular agent shall not be allowed in any manner to interfere with same. 22

Through this contract, Ismail avoided the uncontrollable situation he had encountered with the French military mission.

The men began arriving in groups of twos and threes in early 1870. Mott and his first officers, General William W. Loring and General Henry H. Sibley, arrived on January $27,1870.23$ The other officers arrived soon afterwards. The general procedure for the new arrivals followed a predictable pattern. The group would arrive in Alexandria and be met by one of the already acclimatized American officers. They would then be taken to Cairo and settled in a hotel. Within hours a

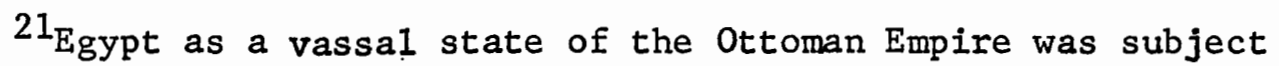
to the Capitulations, a series of laws that exempted Europeans from the native court systems within the empire.

$$
22 \text { Dye, P. } 2 \text {. }
$$

23 The United States Consular Despatches, vol. 4, EGYPT: Hale to Fish, desp. 194, January 27, 1870. 
tailor would arrive to take measurements for their new uniform called a stambouli, which would arrive the next day. Such haste in outfitting was necessary in order that the men might be received by the Khedive as soon as possible. The Khedive was very proud to have the American officers in his army and he was always interested in meeting the men. Colonel Charles Chaille-Long described the welcoming address he received from the Khedive and it was probably typical of the greeting those first Americans received:

I welcome you gentlemen to my country. I desire to express to you my appreciation of your prompt response to my invitation. I may say to you in absolute confidence that you are expected to see active service very soon. Your experience with the late war in the States in America, the lack of any selfish interest in Egypt on the part of your country are the motives which suggested Americans for the proposed service. You will encounter much jealousy on the part of the native officers. I ask you to bear it with patience and indulgence. If however it should become insupportable, then you must not hesitate to come to me directly for redress. I count upon your discretion, devotion and zeal to aid me in the establishment of the independence of Egypt. 24

It is not likely that these were the Khedive's exact words, especially regarding, "the establishment of the independence of Egypt." This account was written some years later, but it is valuable because it indicates how Chaille-Long perceived his role in the Egyptian army. The personal assurance of the Khedive's full support, however, was reported by most of the Americans who have left records of their exper-

${ }^{24}$ Chaille-Long, Four Continents, pp. 31-32. 
iences in Egypt. These assurances would become key factors in the morale of this unofficial American military mission.

Within the first five month of 1870 , twenty American officers were hired and ready for work. ${ }^{25}$ The job of making their assignments and coordinating the American efforts fell to General Charles Pomeroy Stone, who was appointed Chief of Staff on March $30,1870 .^{26}$ This position required not on1y supreme organizational skills and understanding of military operations, but such human relations skills as tact and the ability to communicate the needs of his men. General Stone possessed all of these qualities and under his leadership the Americans created a general staff system, fortified the Egyptian coast, reorganized the troops, opened military schools, explored and mapped large areas of northeast Africa.

Stone's qualifications for the position as Ismail's Chief of Staff were substantial. He was an 1845 graduate of the United States Military Academy at West Point. Upon receiving his commission, Stone was assigned an Assistant-Professorship of History, Geography, and Ethics at the Academy. These teaching experiences would be useful

25 The United States Consular Despatches, vol. 6, EGYPT: Butler to Fish, desp. 3, June 4, 1870. See appendix for list of officers.

${ }^{26}$ Pierre Crabites, Ismail the Maligned (London: George Rutledge \& Sons, Ltd., 1958), p. 96. 
in Egypt. His second tour at Fort Monroe, Virginia, as an inspector of an ammunition factory, would be helpful as well. Stone gained practical. instruction in both the manufacture of amminition and in the actual handling of batteries of siege artillery. This assignment was followed by wartime duty under General Winfield Scott at Vera Cruz and Mexico City. In July, 1848, Stone took a leave of absence to visit Europe. He spent his first month in Paris perfecting his French, and then he traveled throughout the continent to observe the various armies of Europe. Stone's command of French would serve him well in Egypt, and his familiarity with continental military practices no doubt added depth to his experiences in the United States. On his return, Stone completed two tours in the San Francisco area and resigned in 1857 to try his hand at a civilian career. Important for his Egyptian experience was his role in a scientific comission to survey and explore Sonora, Mexico. ${ }^{27}$ A geographer at heart, Stone took great pride in the general staff explorations of a similar nature in Africa.

General Stone ran afoul of the civilian authorities during the Civil Wax. He had reenlisted at the beginning of the conflict, and he was responsible for the rapidly established fortification of Washington, D. C. However, when a company from his command led by

\footnotetext{
$27_{\text {Fitz-John Porter, Annual Reports of the Association of Graduates }}$ (West Point; N. Y.: U.S. Millitary Academy, 1887), pp. 41-44.
} 
the popular, Colonel Edward D. Baker, a former Republican Senator and close friend of President Lincoln, was ambushed and annihilated at Ball's Bluff, Stone's problems began. ${ }^{28}$ The Union forces had à dismal record in the first years of the war and Congress was looking for a scape goat. They found one in General Stone. Stone was investigated for treason, and he was imprisoned for six months at Fort Lafayette in the New York harbor. All of this was done without an open trial or court martial. Stone's release was equally unheralded and without full explanation. Stone bore the injustice with dignity and continued to serve in the Union army for most of the war until he received an unannounced and unjustified demotion. With that he resigned from the United States Army for the last time. 29

Part of the explanation for such arbitrary and unjust treatment lay in the personality of General Stone himself. He was a product of the conservative military establishment. While described as "a most charming and amiable gentlemen: honest, brave and a good soldier," by his superiors, he was considered a stickler for petty rules and a martinet by his soldiers. ${ }^{30}$ He was a part of the military establish-

${ }^{28}$ Colonel Baker was the senator from Oregon for whom Baker County is named.

${ }^{29}$ Harry Williams, "Investigation 1862," American Heritage 6(December, 1954), pp. 17-21.

${ }^{30}$ George B. McClellen, McClellen's Own Story (New York: 'Charles L. Webster, 1887), p. 139; and Williams, p. 18. 
ment that believed that if a war was to be fought, it ought to be left to the military. These qualities did not endear him to his own men, who were quite willing to testify against Stone on hearsay evidence. Nor did the Congress or the press appreciate his stiff, military manner. Essentially Stone was a capable and honest military officer who lacked the natural political instincts which might have prevented this fiasco. However, Stone learned a great deal from his experience and he used his acquired instinct daily as Chief of Staff for Ismail. He worked quietly keeping in the background and in his first years in Egypt few of the high officials were aware of his rising influence. 31 The first item on Stone's agenda as Chief of Staff was to assess the condition of the Khedive's armed forces. The American officers were assigned to various tasks such as inspecting the condition of the coastal fortifications, armaments, and military organization, and they sent their reports to General Stone in Cairo. Stone compiled a memorandum dated December 15, 1870, of the findings for Ismail. $^{32}$ He began by listing nine areas that he felt needed immediate changes or improvements. Beginning with the most serious flaw, Stone stated that more than one-third of the officer corps was illiterate while over 90 percent of the rank and file could neither read nor

$31_{\text {Morgan, p. } 302 .}$

${ }^{32}$ Abdin Archives, Periode Ismail, doss. 50/1, December 15, 1870. 
write their own names. Said Pasha, Ismail's predecessor, had a tendency to promote the uneducated officers over the educated men which increased the inefficiency of the army. A suspicion ridden atmosphere among the officers developed, and there was: much jealousy on the part of the higher ranking but illiterate officers towards the younger, educated men. This atmosphere discouraged attempts to upgrade the literacy level of the officers. An irritating byproduct of this situation was the substantial powers wielded by the literate, civilian clerks of the officers. These men were able to influence and control the officers who could not read the reports sent to headquarters. Stone felt this environment was intolerable. 33

The second and third items on General Stone's list concerned the deteriorated condition of the coastal defences and the complete absence of a torpedo corps or signal service. He compared the crumbling condition of the Egyptian forts and their obsolete armaments to those of the United States which Stone felt were inexcusably weak. The innovative use of torpedoes and submarines during the Civil War had convinced Stone that a modern defense system would be incomplete without them. In addition to these notes, Stone insisted that a secret code be adopted for future military communications. 34

${ }^{33}$ Charles P. Stone, "Military Affairs in Egypt," Military Service Institution of the United States Journal 5 (1884), p. 168. ${ }^{34}$ Ibid. 
Likewise, items four through nine concerned various irregularities in the Egyptian military organization and their general weakness wherever armaments were involved. In point four Stone stressed Egypt's need of an independent ammunition supply. Egypt's reliance on imported ammunition from Europe had to be minimized. Item five reported the absence of a staff system. A general staff had existed under Muhamad Ali, but it had been allowed to disappear and the current high ranking officers had been promoted to their present ranks without the experience of a general staff hierarchy. The inspection of the Egyptian armories and depots uncovered the sixth and seventh problems of Stone's 1ist. The field artillery was obsolete and the military depots were depleted of construction materials. Point eight noted insufficient deliniation between commands. The American officers did not recognize the village and tribal organization in effect within the various divisions and they suggested a clear line of command complete with brigades, platoons, battalions, and companies be established. Furthermore, Stone reported that there was a need for a uniform drill procedure. Each and every comander seemed to have his own idea as to what was necessary and correct. Stone's last point concerned the need for a separate pay department, quartermaster department and comissariat. The Americans were distressed to learn that each colonel would draw the monthly salary for his regiment directly from the War Department's treasury and the same procedure held true for procuring rations and ordnance 
supplies.

The general disorganization was appalling to the American officers' sense of order. The possibilities for confusion and corruption were infinite, and if they were going to train the Egyptian army for action, substantial changes were in order. Stone's report was' the quintessential description of the Pasha system. It is doubtful that at that early date, he or any of the American officers fully comprehended the extensive pasha network that they were to confront. The intransigence of the pashas revealed itself slowly, because they, like the Americans, did not fully comprehend the scope of the changes being proposed.

General Stone had a solution for the nine problems presented to the Khedive. He believed that a full general staff system should be introduced to the army and in a rather original report to Ismail, Stone described the army and its functions in terms of the human body:

- . the staff represents the nerves--starting from the head, which represents the Commander-in-Chief, and extending through, all the various members. That, as the nerves communicate to the brain the exact condition and wants of the members so the staff commuicates to the Commander-in-Chief the condition and wants of even the smallest fraction of the army. And as the nerves communicate the will of the brain to all the members of the body, so the staff, in its various branches, communicates the orders of the Commander-in-Chief to the different units of the army, and provides for and watches over the execution of

${ }^{35}$ Stone, "Military Affairs," pp. 168-69. 
such orders. That a staff is of quite as much necessity to an army as the nerves are necessary in the human body. 36

The general staff, or Etat-Major as it was referred to, consisted of six sections and a Cabinet of the Chief. The First Section embodied the same administrative duties as the Adjutant General in the United States Army. 37 The Second Section supervised the collection and conservation of military history materials in a library established for that purpose. The geographical and military expeditions carried out by the American officers were coordinated through the Third Section, while the Fourth Section was responsible for the military justice system and all inspections. The supply duties of the army such as the quartermaster, commissary, and paymaster departments were consolidated in the Fifth Section. The only exceptions to this would be the supplies for the engineer corps, the pontooniers, and the artillery which were to be controlled by the Sixth Section. This last section also covered all ordnance including torpedoes and studies for coastal defense. 38 Ismail was delighted with Stone's complete and comprehensive report. He fully agreed with the plan and ordered the establishment

${ }^{36}$ Ibid., p. 169.

37 Stone, "Military Affairs," p. 169.

${ }^{38}$ Abdin Archives, Periode Ismail, doss. 50/1, no date. 
of a full general staff. ${ }^{39}$ General Stone was well organized, hardworking, and efficient, the kind of man Ismail wanted to reorganize his army. His early enthusiasm for the general staff plan mist have worried the Turkish and Circassian generals of his court. Additional officers could mean less power to share among them. However, traditionally, changes came slowly to the war department; and because no specific reasons for objections to the plan could yet be given, the reorganization by General Stone began in July, 1871, reasonably unhindered. 40

The establishment of a full-fledged military staff system was important to Stone; however, it was not his only goal. He dispatched memoranda on new ideas almost weekly adding to Ismail's favorable impression. As a former history professor, he was distinctly aware of the lessons one could learn from history. In his January 4, 1871 memorandum, Stone noted that of the three most recent invasions on Egyptian soil, two were successful because the defenders did not attack the invaders while they were landing their forces. The one successful defense occurred when the landing forces were met by a barrage of fire, rather than waiting for the troops to reassemble

${ }^{39}$ Abdin Archives, Periode Ismail, doss. 50/1, July 16, 1871; December 14, 1872; and May 15, 1873. The plans for a reorganization spanned a two year period with the most comprehensive one dated May 15,1873 .

$$
40 \text { Stone, "Military Affairs," p. } 170 .
$$


on land. Stone used this example to illustrate the need for a railroad system along the Mediterranean coast of Egypt from Damietta to Port Said. This would allow for the rapid transportation of troops and arms to any spot along the coast where an invading force threatened to land. Stone also noted that the proposed railroad line would be short and simple to build due to the flat nature of the delta land. ${ }^{41}$

In conjunction with this plan, a number of American officers were sent to Alexandria to help improve the coastal defenses. Colonel Beverly Kennon, Jr., a former Confederate naval officer with a flair for innovative engineering designs, was assigned to develop better coastal fortifications. Kennon, constructed a hidden, single gun fort that literally disappeared into the sand. With an ingenious device of his own design, the guns could be raised to the surface, fired, and retrieved out of sight. Unfortunately only one of these forts was ever built. $^{42}$ The financial situation of the Khedive was growing steadily worse and the money went to more pressing priorities. ${ }^{43}$ However, it

${ }^{41}$ Abdin Archives, Periode Ismail, doss. 50/4, January 4, 1871.

42 Frederick J. Cox, "The American Naval Expedition in Egypt," Journal of Modern History 26(1954), p. 173.

${ }^{43}$ Charles Chaille-Long, "Princes of Egypt," Cosmopolitan 26(1899), p. 258. Colonel Chaille-Long suggests that Kennon's forts were not built because of the jealousy of some of his compatriots. However, the growing financial constrictions of the Khedive's government is a far liklier reason. 
is worth noting that this particular fort was the only battery to survive unscathed the bombardment of Alexandria in 1884.

On a less spectacular note, the physical condition of the already existing forts was improved. New earthen parapets, 50 inches thick were built to replace the old masonry at Aboukir, Rosetta, and Damietta. The old muzzle loading batteries were replaced as quickly as the new guns arrived. 44 These improvements did not go unnoticed. Feeling threatened and uncertain as to what his ambitions vassal Ismail was planning, Sultan Abdul Aziz forced the Khedive to dismantle several of the improved fortifications and to ship the new cannons to Constantinople. ${ }^{45}$ It was obvious to all concerned that the American officers were quite capable and that they might be a threat to the status quo.

A memorandum to the Khedive from Stone on February 7, 1871, suggested that the "occupation of the Straits facing Ras Muhamad, as an outpost stronghold of Suez's Gulf," would be strategic. This position was to be fortified with two heavy batteries and connected by a wireless to Suez and Kennah.

If these more conventional coastal defenses were not sufficient, Stone had made plans for a submarine defense program. For this task

${ }^{44}$ Stone, "Military Affairs," p. 173. ${ }^{45}$ Cox, "Naval Mission," p. 175. ${ }^{46}$ Abdin Archives, Periode Ismail, doss. 50/4, February 7, 1871. 
he brought John 0. Lay, a naval architect of Civil War repute, to Egypt to design a torpedo system for the Alexandria harbor. Lay spent most of 1871 at Aboukir designing and testing his new device under the watchful eyes of the local French consul and Turkish envoys. This weapon was a torpedo suspension mine controlled through the use of electrical cables by an operator on land. ${ }^{47}$ The torpedo mechanism was ordered from the United States and a school for training operators was established at Rosetta. This weapon, however, was never used to protect Alexandria harbor as intended. Prior to the British bombardment of the harbor in 1884, a British employee at the Alexandria customs house discovered the detonating device for the torpedo and he was able to destroy it before the Egyptians could use the weapon. 48

Turning his attention to land defense, Stone's memorandum of September 25,1871 , outlined a plan for using the extensive canal system of the Delta as a possible defensive weapon. This was a twopart plan that not on1y discouraged invaders but helped improve the upkeep of the canals. The first part suggested that the silt collected from the yearly dredging be used to build an embankment on one side of the canal. This would create dominating positions for defense on

${ }^{47}$ Cox, "Naval Mission," pp. 173-176.

${ }^{48}$ Baron de Kuse 1, An Englishman's Recollections of Egypt, 18631887 (London: John Lane, The Bodley Head, 1914), pp. 179-183. 
the otherwise level Delta. The second part of the plan provided for strategic innundations, if necessary, to stop an advancing enemy army. This was a particularly promising plan because it would cost no additional money. 49

In conjunction with these defense plans, there was an immediate need to replenish the munitions and construction supplies of the Egyptian army. During the years between 1870 and 1876 , the coastal ports were supplied with new Armstrong guns and 200 rounds of ammunition for each piece. In addition, Krupp field guns and ammunition were brought in large quantities and stored in depots. 50 Orders for Remington rifles from the United States were made, and one of the Khedive's American officers, Colonel Frank Reynolds, was sent to the New York factory to inspect the shipments. ${ }^{51}$ A powder mill and cartridge factory were constructed outside of Cairo. The factory was capable of putting out some 60,000 cartridges a day, thus making Egypt practically independent of foreign supply. ${ }^{52}$ Colonel Thomas Rhett was

${ }^{49}$ Abdin Archives, Periode Ismail, doss. 50/4, September 25, 1871. ${ }^{50}$ Stone, "Military Affairs," p. 175.

$51_{\text {William T. Sherman Papers, }}$ vol. 40, July 14-September 23, 1875, Library of Congress Archives, Prince Hussein to Sherman, Cairo, August 28, 1875 .

52 Stone, "Military Affairs," p. 173; and J. Carlisle McCoan, Egypt As It Is (London: Cassell, Petter, and Galpin, 1877), p. 100. 
in charge of the operation. In addition to stockpiling munitions, Stone saw the need for stockpiling coal. The bituminous coal available in Egypt deteriorated in the air too quickly for storage: Hence, Stone suggested in his February 7, 1871 memorandum that the Khedive order anthracite coal from the United States and store it in Ismailia, Suez, Port Said, and Alexandria. 53

The defense programs represented only a part of Stone's activities. He was equally anxious to improve the staff functions he had designed. For example, the military library in 1870 consisted of three inaccurate maps and a few books in Arabic on infantry tactics. By 1876 the library consisted of over 6,000 books and manuscripts in French, English, Italian, German, Turkish, and Arabic of the best military books and periodicals of Europe. To facilitate the reports beginning to come in from exploration and mapping expeditions, a printing office was established in Cairo. It not only printed these reports, but it issued a monthly magazine in Arabic on military matters and produced the engraved maps that accompanied the reports. 54

In the interest of Egyptian agriculture, Stone introduced a system whereby the fellahin soldiers were able to obtain a leave of

${ }^{53}$ Abdin Archives, Periode Ismail, doss. 50/4, February 7, 1871. Whether or not this order took place is not mentioned in the materials used in this paper.

${ }^{54}$ Stone, "Military Affairs," p. 174. 
absence during planting and harvest seasons. This privilege was used as an incentive to encourage learning and good performances among the men. This action was instigated in an effort not only to improve the morale of the fellahin but also to improve the agricultural production of the country. As a practical measure it also relieved the expenses of the War Department each spring and fall. 55

In Iate 1873 Ismail expressed his approval of General Stone's work by placing the Ministry of Public Works under his dominion as the Seventh Section. 56 Stone had attempted to locate a capable American to serve as an advisor to the Minister of Public Works as early as May, 1872. In a letter to General Sherman, Stone described the Minister as a young, inexperienced prince who needed an older, experienced, and patient advisor. 57 The right man could not be found immediately, and Ismail grew impatient with the existing situation. So the care of the immense system of canals, both irrigation and navigational, fell to the general staff. This included the ongoing projects for the improvement of the harbors of Alexandria and Suez. Stone was prepared

55 Ibid., p. 173. Stone does not explain what would happen if the country were attacked during the spring or fall.

56 United States Consular Despatches, vol. 8, EGYPT: Beardsley to Fish, desp. 151, November 16, 1873.

57 William T. Sherman Papers, vol. 32, February 28-August 5, 1872 , Library of Congress Archives, Stone to Sherman, Cairo, May 29, 1872. The name of the prince was not mentioned in the letter to Sherman or in any of the other material used in this paper. 
for this assignment, and a number of American officers were sent on survey expeditions under the auspices of the Public Works Section. The Ottoman firman of 1873, among other things, gave Ismail the right to enlarge his army lifting all previous restrictions. When the news arrived in Cairo, Stone began the reorganization of the entire military structure of the army. There were to be five divisions: one division of guard troops and four divisions of the line. Each division was to consist of four regiments of infantry, two regiments of cavalry, one regiment of artillery, and one battalion of engineers. The troops of the guard formed the reserve force of the army and those men were allowed to return home after serving a set period of time. A regiment in the infantry consisted of four battalions of eight companies with 100 men, or approximately 13,000 men in an infantry division. A regiment of cavalry consisted of six squadrons of 150 men each or approximately 2,500 men. No mention was made of the size of an engineer battalion. Using these figures one can compute the approximate size of the planned Egyptian army at some $66,000 \mathrm{men}$, an awesome force by Middle East standards. Stone states that the fourth division was never completed so that the army stood at about 60,000 men. Supplementing this substantial force was the Sudanese army of some 30,000 men and their infinite source for recruitment. ${ }^{58}$. Hence, the Khedive's army, ${ }^{58}$ Stone, "Military Affairs," p. 172. 
at least in theory, was a formidable force in Middle Eastern politics.

Throughout the entire reign of Ismail, a series of exploratory expeditions were sent to map the unknown areas of northeast Africa, and often the officers would negotiate treaties of cooperation or actual annexation of the territories for the Khedive. In this role, the American officers excelled. Their treks across unknown and treacherous deserts, swamps, and mountains opened large areas to western view for the first time. General Stone was particularly pleased with their scientific and geographical reports while Ismail was particularly gratified with their expansion of his territory.

Colone1 Erastus Sparrow Purdy, a former Union officer from California, proved to be an especially adept explorer. In his first expedition in 1871, he mapped the regions between Cairo and Suez and Kenneh on the Nile to Kossair on the Red Sea. In early 1874 he was sent on a reconnaissance of the Ababdieh and Bishareen deserts between Berber on the Nile and Berenice on the Red Sea to see if a railroad would be feasible. His report stated there would be no problems except possibly two stretches lacking in water. Between 1874-1876; Purdy along with a fellow American officer Colone1 Alexander Mason, explored the upper Nile to New Dongola then crossed westward to explore and map the route to El-Fasher, the capital of Darfur. There they were joined by their fellow American, Colonel Henry G. Prout, and together they mapped much of Darfur. On that expedition it was discovered that the position of 


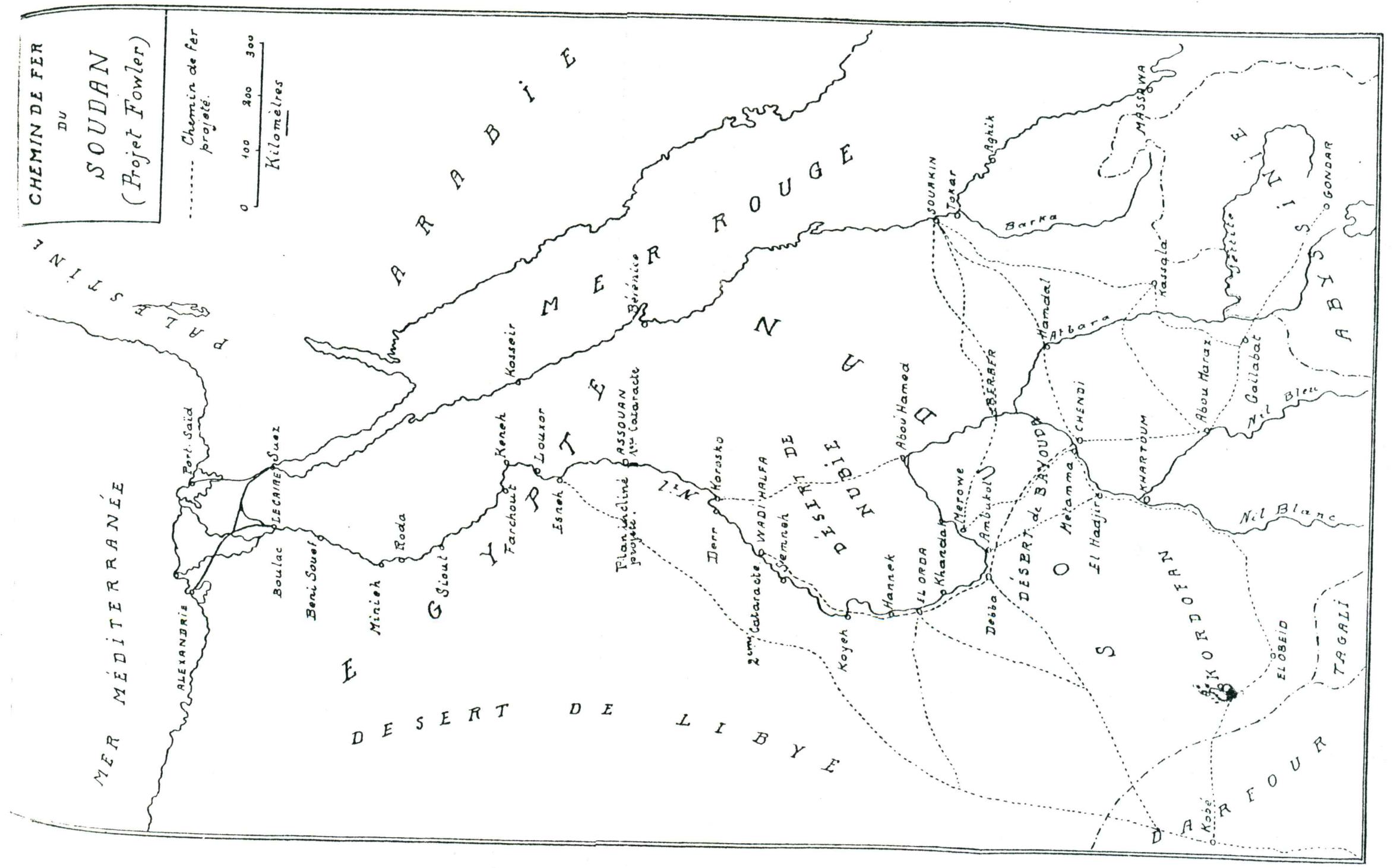

George Douin, Histoire du Règne du Khédive Ismaíl, vol. 3, Part 2, plate XI. 
E1-Fasher was a full three degrees further west than previously mapped. 59 In later years Purdy served as military governor of Darfur.

Colone1 Mason began his Egyptian career as a captain of the Khedival mail steamer that traveled between Alexandria and Constantinople. 60 His first exploratory expedition was to map Fayoum and the oasis of Siwa in western Egypt in 1872. On his next two expeditions, Mason accompanied Purdy on the Ababdieh and Bishareen reconnaissance as well as the Sudanese expedition to Darfur. Mason's final feat as part of the American mission was the circumnavigation and survey of Lake Albert Nyanza in Central Africa. ${ }^{61}$ Mason remained in Egypt as a civilian employee of Khedive Tewfiq after the dismissal of the American mission. He served as the governor of Massawa until the city was given to the Italians in 1885.

Colonel Raleigh Colston, a former Confederate officer and chemistry professor, was first assigned to the Staff College as an instructor. However, he was soon transferred to the Third Section and sent on mapping expeditions. His first effort in 1873 was to explore and map the ancient Roman road from Kenneh to Berenice. He made geological surveys and maps of the deserts between Kenneh and Berbera on the Red

${ }^{59}$ Raleigh Colston, "Stone-Pasha's Work in Geography," Journal of the American Geographical Society of New York 19(1887), pp. 49-59.

${ }^{60}$ Cox, "Naval Mission," p. 173.
$61_{\text {Colston, "Stone Pasha," p. } 50 .}$ 
Sea; in addition, Colonel Colston was a member of the Purdy/Mason expedition of early 1874. Between 1874-1876 Colston ascended the upper Nile to Debbah. During this expedition, he contracted a paralysis and at one point he almost died. However, he showed his phenominal willpower by not relinquishing his command until Colonel Prout arrived to take his place. Prout journeyed from El Obeid to rendezvous with Mason and Purdy. He had been surveying the route between Suakin and Berber when he received the order to relieve the suffering Colston. Colonel Colston eventually returned to Cairo alive, carried on a hamock strung between two camels. 62

Cölonel Charles Chaille-Long had an equally exciting and unique series of expeditions. His first exploratory assignment came in conjunction with his assignment as Chief of Staff for the British Colonel Charles Gordon. ${ }^{6.3}$ They ascended the White Nile in 1874 as far as Gondokoro together. From there Chaille-Long continued with a small retinue to visit $M^{\prime} T e s e$, the King of Uganda. The king agreed to sign the friendship treaty brought by Chaille-Long from the Khedive. On the 1874-M'Tese mission, Chaille-Long ascertained the identity of the White Nile as it merged with the Somerset River and he discovered Lake

62 Ibid., p. 48.

${ }^{63}$ Chaille-Iong, Charles, "Colonel Chaille-Long on the Juba," Journal of the American Geographical Society of New York 19 (1887), pp. 194-198. 
Ibrahim (later renamed Lake Kioga). In 1875 he led an expedition from Lerdo into the country of Makraka-Niam Niams. Chaille-Long!s last expedition took him to the mouth of the Juba River on the African coast in 1876.64

Colonel William $\mathrm{H}$. Ward, formerly a lieutenant in the Confederate navy, worked with John Lay on the torpedo experiments at Aboukir after his arrival in Egypt. Later, because of his linguistic abilities, Ward served as an aide to General Sherman during his 1872 visit to Egypt. In 1875 he surveyed the Greek island of Thasos, noting its economic, strategic, and commercial possibilities along with mapping the island's harbors and land features. This was followed by his trip accompanying Chaille-Long down the coast of Africa the same year. His hydraulic survey of the harbor of Kismayu added to the growing list of American achievements. 65

Some of the American officers had barely arrived in Egypt when they were sent on these exploratory and reconnaissance missions. Colonel Samuel Lockett, Lieutenant Colonel Henry Derrick, and Professor I. J. Mitchel1 explored and mapped the region southwest of Massawa in 1876. Lockett and Derrick had both been military engineers in the Confederate

${ }^{64}$ Colston, "Stone Pasha," p. 49.

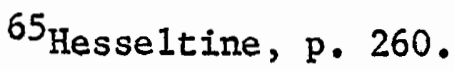


army. Colonel Charles I. Graves, another Confederate naval officer, performed the last reconnaissance assigned by the Third Section. He surveyed and established the first lighthouse at Cape Guardafui at the entrance to the Red Sea in $1878 .^{66}$ The sheer quantity of American expeditions was impressive, but the results were the true test of the men. They contributed a vast store of knowledge to hitherto unknown areas. Ismail displayed his pleasure in their work by awarding numerous medals for their efforts.

Ismail's confidence in his American officers reached its peak in early 1874. The Americans had been in Egypt four years and most of the plans put forth by General Stone had been put into at least partial operation. The Khedive must have felt the urge to try out his rejuvenated forces; and as if he wanted to be obliging, Ferdinand deLesseps, the president of the new Suez Canal Company, almost gave Ismail the opportunity.

Delesseps had found that the revenues from the ships passing through the canal did not reach the expected levels, and he persuaded the Board of Directors to change the method of taxation. Rather than accepting the net tonnage of a ship or tonnage by weight of the cargo, deLesseps decided to impose a tax on the gross tonnage of a ship. This meant 55 percent increases in revenues over the old rate. Needless to say, the uproar from the shipping companies, which were mostly

${ }^{66}$ Colston, "Stone Pasha," p. 50. 
British, was deafening. Sultan Abdul Aziz appointed an international commission to deal with the matter in October, 1873. The results were that delesseps had to discontinue his new taxes. Delesseps requested at least a permanent surtax on the old tomnage rate, and when word of the refusal arrived on April 11, 1874, he threatened to oppose the passage through the canal of any ship that refused to pay his tax. Furthermore, the telegraph cable would be cut, bouys removed, lights extinguished, and pilots would not be provided to guide the vessels through the maze of lakes and canals that made up the Suez Canal. 67

Ismail watched the negotiations between the Porte and the Canal Company carefu1ly. He fully expected a stalemate, and he saw the perfect opportunity in this situation. He immediately offered to occupy the Canal for the Sultan, free of charge, using his new army. The Sultan hesitated briefly, but when the final words of "no compromise" from deLesseps arrived, the Khedive was authorized to take command. General Stone was immediately placed in command of the troops and McKillop Pasha, a former British naval officer, took charge of the naval contingent. Stone organized the action and on April 23, one battalion arrived at Port Said, Ismailia, and Suez to prevent any attempts to sabbotage the canal and to operate the canal if need be. Delesseps was given until April 28, 1874, to comply with the

67 Frederick J. Cox, "The Suez Canal Incident of 1874," Cahiers d'Histoire Egyptienne 4(October, 1952), pp. 8-9. 
Sultan's command. In a fit of arrogance, delesseps had left for Jerusalem disregarding all of the threats until he heard the news of General Stone's arrival in Port Said. At that point delessep's realized that the Sultan intended to enforce his will; he immediately returned to Cairo and in an interview with Ismail on April 25, 1874, he made his peace and consented to the Sultan's terms. 68 One can almost sense the keen disappointment of Ismail. He had almost been allowed to take over the Suez Canal. This would have given him new opportunities for revenue and possibly even nullified his financial obligations to the Canal Company. As this was not to be, he was ordered by the Porte to remove his troops immediately. In spite of the setback, Ismail must have received a certain amount of satisfaction for having called delesseps game.

In spite of the many successes credited to the American officers, all was not wel1 within the American mission. Traces of the impending difficulties had been evident from the arrival of the first officers. Khedive Ismail requestèd their forebearance, and he promised to rectify any wrong done to them. Consequently the first unpleasant and/or discouraging incidents were dismissed patiently. The Americans felt that their various achievements in the technical fields would soon earn the respect of the Egyptian establishment that was so determined to 
resist them. However, as the years went by and the harassment increased, the American officers began to perceive the many faces of the "pasha system." The depth of their cultural differences was staggering. 


\section{CHAPTER IV}

\section{THE CONFIICT BETWEEN THE PASHAS AND THE AMERICANS}

One of the American officers was quoted in the New York Times of July 27, 1871, saying that the "Khedive treated his American officers well but his subordinates were undecorous and insulting at times." Had that been the extent of their problems with the pashas their mission might have succeeded. But the American officers were on a collision course with the Egyptian pashas from the start. The first incidents were usually frustrating and sometimes rather amusing. Their initial experiences were passed off as minor irritations. The officers held their ground firmly and refused to accept treatment they felt insulting or otherwise improper for officers of their rank. Now and then an officer would complain directly to the Khedive, and his satisfaction was more than assured; oriental punishments were sometimes disconcertingly harsh. Nevertheless, the Americans were reasonably content as long as they could see progress in their work and they could have their views taken directly to the Khedive. Captain James M. Morgan, a brash young, former naval officer in the Confederate navy, experienced his first confrontation on his first day in Egypt. He arrived in Alexandria with a party of Americans and no one came to meet them. They did, however, receive word to report to Ali Bey, an 
official from some unknown bureau, the next morning. The men, Morgan among them, arrived promptly but they were left waiting for several hours. Ali Bey finally made his appearance and he proceeded to inform the men that they were neither needed nor wanted in Egypt. He then singled out young Morgan by informing him that he was too young for his rank and that he must accept a lower position.

Already annoyed by the long delay, Morgan lashed out at Ali Bey in English, telling him that he was employed by the Khedive and no minor official was going to demote him. Apparently the startled official had some knowledge of English and he quickly backed down and informed the men that arrangements had been made for their transportation to Cairo on the following day. Prior to their departure, Morgan received a request from Ali Bey to kindly forget the incident and not mention it to the Khedive.1 Properly mollified, Morgan took this incident as encouragement to always stand up for what he perceived as a "gentleman's" rights. Morgan's relatively short Egyptian career was strewn with such incidents.

Not all incidents could be resolved by the American officers' actions alone. Colonel Chaille-Long was assigned to the lst Division of Infantry, 1st Corps to organize a staff service for the commanding General Halid Pasha. The pasha had never worked with a staff officer before and he did not intend to either. He saw Chaille-Long's presence as an infringement upon his power and prerogatives, and to make matters worse, Chaille-Long's

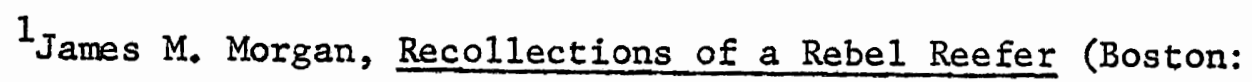
Houghton Mifflin Company, 1917), p. 268. 
pompous manner and elaborate wardrobe of uniforms were highly offensive to the pasha's sense of propriety. Halid Pasha regarded him as a useless and meddlesome foreigner. As Chaille-Long recounts the experience, he was "subjected to every species of annoyance on the part of Halid, who not only refused to comply with the letter and the spirit of my (Chaille-Long's) instruction but withheld my pay during several months." 2 Eventually Chaille-Iong could take the insolence and withheld pay situation of his commander no longer, and he requested an audience with Ismail. It was arranged and when Ismail heard Chaille-Long's tale of indignities, he reacted immediately. General Halid Pasha was reassigned to New Dongola in the Sudan, a city whose sole distinction was that few Egyptian officers ever returned from that assignment alive. ${ }^{3}$ Like Morgan, Chaille-Long felt that he received his retribution, if not a trifle more severe than he expected.

In the early years of the mission the Khedive's full support of his American officers was publicly demonstrated on a number of occasions. Captain Morgan, once again, was the party involved in the following incident. One of the benefits of being stationed in Cairo was the availability of free tickets to the various cultural events in the city. As part of the spectacular opening ceremonies for the Suez Canal, Ismail built a grand opera house along with a number of theaters and other

${ }^{2}$ Charles Chaille-Long, My Life on Four Continents (London: Hutchins on and Company, 1912), p. 53 .

${ }^{3}$ Ibid., p. 54. 
cultural attractions. The American officers were delighted to partake of the open admission provided to them by the Khedive. On one such occasion at the Theatre Francais, Ali Bey the Prefect of Police demanded that Captain Morgan serve him a glass of water. Both mortified and angered by the menial task demanded of him, Morgan quickly obtained the water and proceeded to toss it in the Prefect's face. Furious, Ali Bey dashed to the Khedive's box and related the incident. To his humiliation, the Khedive asked him:
"What did you do to provoke the American officer?". . " "I requested him to give me a glass of water," replied the Prefect of Police. "Did he give it to you?" queried Ismail Pasha. "No, Your Highness, he threw the water in my face and slapped me." "Ali Bey," said his Sovereign, "I should have been dis- appointed had he not done so. I did not bring Americans here to wait on you or upon anybody else. You may consider your- self fortunate that he did not shoot you. Go now and ask his pardon and see that you do not insult another American officer." $" 4$

Such public support of these Christian foreigners put the pashas on their guard. If they could not defeat them in open confrontation, then they would have to work quietly around the Americans.

This Iine of offense was very effective as General Loring quickly discovered. After several months of inspecting the condition of the army and reporting his findings to General Stone, Loring was named commander of the 1st Army Corps stationed in Alexandria. 5 On

\footnotetext{
${ }^{4}$ Chaille-Long, Four Continents, pp. 17-18.

${ }^{5}$ Ibid., p. 39.
} 
arrival at camp, he discovered that the military headquarters did not have a guard unit. He immediately requisitioned from Khalid Pasha, his second in command, ten soldiers for assignment to guard duty. Khalid Pasha had never felt the necessity of a ten-man guard for his headquarters, and he saw no reason to obey an order from a foreign officer. He bluntly informed General Loring that the corps could not spare ten men for such a job. Loring was furious; there were over 12,000 men in the corps. The matter was referred to the Minister of War who upheld the arguments of his fellow pasha. 6

General Loring's problems continued to grow. Khalid Pasha would not acknowledge the staff system imposed upon the corps. He would insist upon conferring with the Minister of War on all matters, often directing orders to the corps unbeknownst to General Loring, the appointed Commander-in-Chief. Feeling the situation was beyond his control, Loring addressed a letter directly to the Khedive, seconded by one from General Stone, requesting a replacement for Khalid Pasha, preferably a "young, ambitious, and educated general or colonel. . " ${ }^{7}$ Whether or not Loring ever received a replacement for his second in command is. not recorded. However, the incident typified the American experience in Egypt.

General Stone was not blind to the passive resistance that his

6Morgan, p. 297.

${ }^{7}$ Abdin Archives, Periode Ismail, doss. 50/1, June 17, 1871. 
reorganization plans and programs were receiving from the pashas. 'In fact, he developed another plan that he felt would eventually override their opposition. Stone believed that a large part of the resistance was due to the lack of proper education on the part of the military officers, and he wanted this situation remedied. He took this problem to Ismail and argued his case convincingly. In August of 1870 the Khedive ordered that henceforth all promotions would be contingent upon whether the officer or soldier could read and write. 8 This was a drastic measure and it might have fostered insurmountable resentment and resistance had it not been for the second part of Stone's plan. Henceforward one and a half hours a day were set aside for classes for the entire army.

The reasoning behind this action was two-fold. Stone felt that the Coptic clerks of the illiterate officers had a stranglehold on their chiefs. If the army were to become efficient and accountable, the clerk positions must be filled by educated, military men; men whose interests lay with the army rather than solely with their family clan. Never before had there been enough educated soldiers to fill the clerk positions. Stone's plan would produce a sufficient number of literate

${ }^{8}$ Charles P. Stone, "Military Affairs in Egypt," The Military Service Institution of the United States Journal 5(1884), p. 171. Stone felt that the illiteracy problems was so important that it was one of the first plans he submitted to Ismail. 
soldiers to permanently unseat the scheming, civilian clerks. The second consideration arose from the petty jealousy that separated officers along educational lines. As mentioned previously, a number of uneducated officers had risen to high ranks under the rule of Said Pasha. Their fear and distrust of the younger and educated officers was understandable. If, however, they could develop even a sma1l degree of literary competence and added self-confidence from Stone's reforms, perhaps some of their suspicions would disappear. This would certainly help the overall morale of the officer corps, and more importantly, it would no longer discourage the younger officers from continuing their education. The resulting educated, intelligent soldiers, hopefully, would be capable of mastering the latest military technology brought by the American officers.

A general rise in the literacy skills of the armed forces would have been a tremendous achievement in itself, but General Stone wanted more. Under his leadership a wide variety of specialized schools were established, most notable, the Staff College in Abbassiah. It was organized in much the same manner as West Point allowing for cultural differences. ${ }^{10}$ Many of the American officers were assigned to it at one time or another as instructors of chemistry, engineering, geography and other technical subjects. The students chosen for the Staff College ${ }^{10}$ Stone, "Military Affairs," p. 171. 
were considered the brightest graduates of the military preparatory schools. They were to continue their education for an additional year while the less industrious students were assigned directly to military. duty. The students of the Staff College were to receive the same pay as their former classmates and after the extra twelve months of studies, they too would enter the military service as sub-lieutenants. ${ }^{11}$

In addition to the Staff College, a number of specialized schools were established. There was an artillery school, where both junior officers and non-comissioned officers learned the fundamentals of artillery warfare along with the care and functions of the newly imported military equipment. ${ }^{12}$ A school to train men in the use of the new submarine equipment was opened at Rosetta. A special school: to help establish uniform drill measures was opened at the Citadel in Cairo. One sergeant and one corporal from every company in the army were. chosen to attend the course. They formed two model battalions which were instructed in the fundamentals of the newly established drills, rules, and regulations of the Egyptian army. After their one-year course, which also included instruction in the basic educational skills, the

11 William McE. Dye, Moslem Egypt and Christian Abyssinia (New York: Atkins and Prout, 1880; reprint ed., New York: Negro University Press, 1969), p. 71.

12 Stone, "Military Affairs," p. 173. Stone does not mention the location of this training school. 
men returned to their former companies to impart their knowledge to their fellow soldiers. New men were then sent to Cairo to fill the next year's class. In this way, a uniform drill was to be passed on to all the regiments, battalions, and companies in the army. 13 An interesting side effect developed from the battalion school. The fellahin assigned to this course in Cairo brought their families with them. 14 When General Stone discovered that the men were bringing their sons to class with them, he decided that this unexpected dedication ought to be utilized: He suggested to the Khedive that a special school for the sons of the non-commissioned officers attending the battalion school be established. Ismail, who was very concerned with education, gladly obliged, and the school was opened in 1874.15 In addition to the education of these boys, Stone felt that this program should be considered a special right for the conscripted fellahin who achieved the battalion school. The fellahin were afforded precious few advantages for their military services and this was a good opportunity to improve their lot.

The results of this massive military education program were fairly immediate and dramatic. Stone reports that by 1873 "fully

$$
\begin{aligned}
& { }^{13} \text { Ibid., p. } 172 . \\
& { }^{14} \text { Ibid., p. } 173 .
\end{aligned}
$$

$15 \mathrm{~J}$. Heyworth-Dunne, An Introduction to the History of Education in Modern Egypt (London: Luzac \& Co., 1938), p. 350. 
seventy five percent of the rank and file of the army could read and write, and knew more or less of arithmetic and the geography of Africa." 16 The Staff College graduates showed promise as well. In 1873 they graduated twenty young lieutenants capable of drawing maps and in filling some of the engineering positions formerly held by Europeans. ${ }^{17}$ This had the effect of lessening some of the technological dependence of Egypt upon the Europeans, and it saved the Khedive money in salaries since a native officer could work at a salary a fraction of what a European engineer commanded. In spite of the seeming success of the educational process, serious problems still developed. The pashas were not to be outdone by a few school teachers.

The pashas seemed to instinctively recoil from all of this American activity. Their actions were designed to stall or at least slow down the American projects. Keeping the example of Halid Pasha's transfer to New Dongola in mind, the Circassian and Turkish pashas moved carefully but decisively. The American officers assigned to fill a staff function under a pasha found very little with which to occupy himself. The pasha would continue to run his organization as he had in the past. Not a few Americans found themselves sitting around in the local coffee houses catching up on the latest court

${ }^{16}$ Stone, "Military Affairs," p. 171.

17 William T. Sherman Papers, vol. 36, 1873-1874, Library of Congress Archives, Stone to Sherman, Cairo, December 18, 1873. 
gossip. $^{18}$ The only advantage the pasha could see in the intruding staff officer was the prestige he might gain by having one of the Khedive's American officers under his command. General Ratib Pasha, the Commanding General of the Army, ordered one of his American staff officers to appear in full dress uniform at the home of a French actress with whom he was intrigued. The staff officer was no less than the indomitable Captain Morgan, and natural1y, he refused to obey the order, to the consternation of his commander. 19 In general, the pashas disliked and distrusted the American staff officers even if they did appreciate their decorative value.

The Minister of War was of the same opinion. As General Loring described him, "the Minister of War, though extremely amiable, looked upon the interference of the staff as an infringement of his rights and dignity, and a deprivation of a certain share of prestige." 20 The Minister of War continued his practice of issuing all orders directly to the commanding officers with the exception of the Americans, and the commanding officers continued to correspond directly with the Minister. The effect of this dichotomy of wills was that the Minister

18 Morgan, p. 274 . 19 Ibid., p. 301. 20 William W. Loring, A Confederate Soldier in Egypt (New York: Dodd, Mead \& Company, 1884), p. 358. 
of War controlled the bulk of the army, and General Stone and his general staff functioned as an isolated unit rather than the "nerve system" of the army. Colonel Dye suggested that General Stone may have felt he could convince Prince Hussein, the young Minister of War, that the general staff added to his prestige rather than detracted from his position, but Dye concluded that he was unsuccessful. ${ }^{21}$

The Americans also found that some of their most important reforms were rescinded and some ideas were never instituted. The Staff College had been established as a reward for those officers who proved themselves as aspiring students. Their extra year of studies was to be considered a distinct advantage in one's military career. Upon graduation, the student entered the army at the same rank as his former classmates. Unfortunately, this system did not last long. The measure was repealed and the brighter students lost a year of seniority for their efforts. Furthermore, they found their reception by the pashas restrained when they did enter the 1 ine. ${ }^{22}$ The reality of this system did not encourage good scholarship and the general staff suffered for its 1oss. The traditional pashas had other successes as we11. The Americans had requested but never obtained a three-year draft. ${ }^{23}$

${ }^{21}$ Dye, p. 74 .

${ }^{22}$ Pierre Crabites, Americans in the Egyptian Army (London: George Rutledge \& Sons, Ltd., 1933), p. 48. Although there were several references to this reversal, no specific date was given. ${ }^{23}$ Dye, p. 57. 
That would have limited the baksheesh the pashas procured from the frequent call for recruits. The road to military reform was more difficult than the Americans had imagined.

Outside of Sections Two and Three, the mflitary history and exploratory sections, the general staff that Stone set up existed mostly on paper. Officers might be assigned to take care of the quartermaster or ordnance duties, but they seldom exercised any real authority. The native officers, once again, insisted upon taking charge and commicating directly with the Minister of War. In some instances the pasha was quite efficient and accountable, as in the case of Effletoun Pasha who controlled the ordnance department, independent of the general staff. ${ }^{24}$ However, more often than not, the military functions continued in the same haphazard fashion the Americans had found on their arrival in Egypt.

In genera1, the Americans were not put in direct command of the troops, and in consequence, the army lost many of the benefits of their experience and knowledge. The pashas probably appreciated this policy but in this case it was not entirely due to their objections. In the early years of the American presence, General Stone assigned several officers as commanders but only for a few days. In General Loring's case, while he did remain in command of the 1st Corps in

$$
{ }^{24} \text { Ibid., p. } 78 .
$$


Alexandria for some five years, he possessed only the semblance of authority. 25

The reason for Stone's reticence probably stemmed from his experience with Colonel Walter $\mathrm{H}$. Jennifer, a former cavalry officer in the Confederate army. Jennifer was assigned as commander of a bedouin cavalry battalion. The beduoins have been reknowned for their horsemenship throughout the ages, and they hardly needed instructions from an American officer. However, in addition to their superb horsemenship, the bedouins have been known for a certain independence of will, or as Colonel Jennifer saw it, pure insubordination and unruliness. The combination of a southern officer and the desert bedouins could not last long, and seeing the hopelessness of the situation, Stone relieved Jennifer of his duties. Unfortunately, Jennifer was suffering from a severe case of culture shock and he never adjusted to life in Egypt. He resigned after one year's service. Stone prevented further confrontations of this nature by limiting the direct contact between his American officers and the natives. 26

These discreet but nonetheless debilitating conflicts between the traditional Turkish and Circassian officers and the Americans should have been halted by Ismail, as the ultimate Commander-in-Chief

$$
25 \text { Dye, p. } 77 .
$$

26 William B. Hesseltine and Hazel C. Wolf, The Blue and Gray on the Nile (Chicago: University of Chicago Press), p. 82. 
of the army. However, by 1878 , the absolute support Ismail had guaranteed the Americans had begun to diminish. There were a number of reasons for this gradual reversal. Foremost among them was that Ismail's chronic financial woes had taken a turn for the worse. The European bondholders held the upper hand and Ismail could not afford to alienate those few traditional groups that still supported him, particularly his milizary pashas. Technically, the Muhammad Ali dynasty was Turkish not Egyptian; consequently, Ismail was a foreigner in his own country. Should the Europeans want him deposed, it was not likely the overtaxed, overworked, and over-conscripted Egyptian fellah would be sympathetic to his cause. Thus Ismail was forced to cultivate his fellow Turks as his only loyal, popular support.

In addition to his growing financial plight, Ismail had not been trained as a military leader. It is doubtful that he fully understood the necessity of a clear line of command in the American reorganization plans. It would have been easy for Ismail to agree to a new regulation requested by General Stone one day and award some special privilege that directly violated the new regulation to one of his Turkish generals the next day. Furthermore, Ismail probably never saw the contradiction. An additional element that colored the situation should be mentioned. The large amounts of sheer self-serving flattery showered on the Khedive by the pashas and the continual stream of baksheesh were almost more than the Americans could bear. How important this may have been is a moot question, but it certainly irritated 
the American officers. Many felt that nothing would ever be achieved without baksheesh, but they refused to stoop to such a custom and they maintained their own Americans standards of honor throughout their stay in Egypt. 27

If these problems, although not entirely of their own making, were not enough, the American officers managed to create a number of their own difficulties. One habit, often tolerated in the United States but absolutely unacceptable in Muslim Egypt, was the public consumption of alcohol. This offense was taken unusually hard since the Qur'an, the holy book of Islam, expressly forbids the use of alcohol. Fortunately, there were very few serious cases. However, when problems arose, they created a very poor impression among the natives. General Henry Sibley one of the first officers to arrive in Egypt, served as a particularly poor example of American conduct. His drinking problem had obviously developed long before he arrived in Egypt. However, the frequency of his drinking bouts and his consequent incompetence soon became too severe for the Egyptians and even his fellow Americans to disregard. He was discharged in 1873 for a "physical disability." 28 A similar case involved Major D. G. White, formerly of the Confederate army. Described by one of his fellow officers as a man of little brains and

$$
\begin{aligned}
& 27 \text { Dye, p. } 72 . \\
& { }^{28} \text { Hesse1tine, p. } 113 .
\end{aligned}
$$


less capacity, White managed to over imbibe before reporting to work each morning. He had volunteered for the Egyptian service and apparently General Mott had not checked his record closely before enlisting his services. Ultimately, White deserted in December, $1875 .^{29}$ Such debauchery was embarrassing to the American reputation.

A problem far more prevalent among the Americans was their seeming inability to live within their means. There are numerous cases where the local merchants and landlords took an officer to court over his indebtedness. Not surprisingly, General Sibley was one of the most frequent offenders. On his departure from Egypt he left unpaid bills on everything imaginable from broken and damaged furniture, smashed glasses and dishes, liquors and cheeses to gold mounted coral studs, gold epaulettes, postage stamps, and books not to mention his rent. Colonel Alexander Reynolds, one of the many West Point officers who had fought with the Confederate army, had similar debts. His bills ranged from clothing, books and wine to groceries, medicine, and even a contribution to the memorial fund for the recently deceased American Consul General R. Beardsley. Colonel Reynolds' affairs had to be untangled by the American Consul in Alexandria after he died there in 1876.30

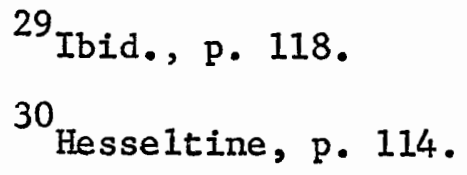


A large number of the debt problems concerned rent and uniform bills. Major Cornelius Hunt, a former master's mate in the Confederate navy, brought his wife to Egypt and rented a furnished house in Ramleh, a fashionable suburb of Alexandria. He not only refused to sign a contract but he also failed to pay the entire sum of rent each month and then tampered with the receipts to show full payment. ${ }^{31}$ His case was sent to the American Consul for adjudication. Unfortunately, Major Hunt died of a fall from his horse in 1873 with his case still pending. This financially irresponsible attitude towards native merchants and landlords did not win many friends among the Egyptians.

Colonel Purdy had his problems as well. He owed some 384 pounds for room and board at the Khedive's hotel. He had tried to argue that it was the government's duty to pay his upkeep but the judge ruled in favor of the hotel manager. It is likely that the man exaggerated Purdy's bill, nevertheless, by admitting that he had not paid any of his room and board, Purdy became liable for the entire bill. ${ }^{32}$ Major Wilburn Hall, onetime lieutenant in the Confederate navy, left a sixmonth lease unpaid when he went on leave in 1876 never to return to Egypt again. Fortunately, the Assistant-Consul of the United States in Cairo was able to sub-lease the house and cover the bill. 33

$$
\begin{aligned}
& 31_{\text {Ibid., pp. } 112-113 .} \\
& { }^{32} \text { Ibid., p. } 115 . \\
& { }^{33} \text { Ibid. }
\end{aligned}
$$


Colonel $W$. Dunlop tried to use the same argument of responsibility as Purdy when he was brought to court over the payment for his uniform. He claimed that since it was a military expense, the Egyptian government should pay the bill of some 690 francs. He paid his debt only after the American Consul moved to attach a garnishment on his salary. 34

A partial excuse for this cavalier financial behavior can be offered. Pay days in the Egyptian army were erratic and often delayed for months at a time. This became more and more frequent in the later years of the American mission as Ismail's treasury sunk further into bankruptcy. There were times when the officers were unable to pay for their legitimate needs. However, not all of the debts, as was shown, can be blamed on "payless paydays." 35 The reputation of the American officers suffered as a result of these abuses.

A contributing factor to the many problems of the American mission was the varying linguistic abilities of the men. A large proportion of them were fluent in French when they arrived, and this proved very useful in Cairo and Alexandria. However, only the upper echelon officials, princes, and some generals spoke French. When the officers left for the hinterlands, a fair knowledge of Arabic or an interpreter was required. Most of the officers who led the various exploratory expeditions learned the colloquial Arabic quickly, and

\footnotetext{
${ }^{34}$ Hesse1tine, p. 113.

35 Those were Colonel Lockett's words for the situation.
} 
consequently they functioned we11. It was the men who did not have a sufficient command of either language that caused the problems. General Loring, one of the oldest officers in his mid-sixties, never fully mastered French. Many a conflict arose due to the resulting commication gap as will be illustrated later. General Stone tried to minimize this language problem by insisting that the men General Sherman recommended to him be fluent in French. ${ }^{36}$ Nevertheless, the American officers continued to converse in English among themselves, and those officers whose French was weak did not get the opportunity to improve their language skills. ${ }^{37}$ The communication barriers were difficult and sometimes impossible to overcome.

In a more general sense, the American officers and their families did not really adjust to the Egyptian culture, although there were a few prominent exceptions. ${ }^{38}$. The Americans tended to socialize only among themselves. The Stone household was the recognized center of social activities and their normal guests included the officers, the American Consuls, and the few American missionaries in Egypt. William Hesseltine, one of the few historians to write about the Americans in

36 William T. Sherman Papers, August 6-October 26, 1872, Library of Congress Archives, vol. 33, Stone to Sherman, August 31, 1873.

37 Henry C. Derrick Letters, $1875-78$, in private possession, Derrick to Derrick, Cairo, 非20, June 7, 1876 and 非16, Apri1 20, 1877.

38 Hesse1tine, pp. 90-119. Most noticeably the men who led the many expeditions tended to adjust better to this foreign culture. 
Egypt, points out that in the eight years that the Americans lived in Egypt, none of the bachelor officers married Egyptian wives nor did any of the daughters of the officers marry native husbands. 39 The Americans lived apart from the Egyptian world in their own transplanted American society. With such insulation, it is not surprizing that many of the officers could not deal with the petty irritations aimed at them by their pasha counterparts in the early years, much less the greater obstacles in the later years of their mission. Rather than studying the traditional. Islamic culture and appreciating or at least comprehending it, most of the Americans tried to use their own cultural standards as a basis for their judgments. The results were sometimes humorous, more often disastrous, as will be exemplified by the Abyssinian campaign of 1875-76 later in this paper.

General Stone, the Chief of Staff and ranking officer among the Americans, served as their chief spokesman, concilliator, and protector. It was not an easy position to fulfill judging by the ever present passive resistance provided by the pashas and the irresponsible and sometimes illegal activities of the American officers. In addition to dealing with conflicts arising between the natives and the Americans, Stone had to keep peace among his own men. Considering that most of men had fought against each other a decade earlier, incidents were

${ }^{39}$ Ibid. The two chapters, "Delta Days" and "Problems of a Pasha" which detail the American maladjustment are excellent. 
exceedingly rare, but not non-exsistent.

One such incident concerned the American Consul General George Butler, nephew of the radical, Republican Senator Benjamin Butler, better known to the South as Beast Butler, and three former confederate officers, General Loring, Colonel A. Reynolds, and Major Campbe11. Butler and two drunken accomplices, assaulted the three officers in a restaurant after a brief exchange of greetings. Butler, nursing a grievance, insulted Major Campbell and when he turned to respond, the Consul General rushed at him. Campbell defended himself with a cane and Butler shouted to one of his friends to kill him. The unfortunate Campbell was shot in the leg and Butler and his accomplices fled the premises. The Egyptian police were called but Consul General Butler claimed diplomatic immunity for his trigger-happy friend. Both the Consul and the culprit boarded the evening steamer for Brindisi but not before Butler had cabled Washington saying that there was a Confederate plot to assassinate him. 40 Butler had already damaged his own reputation in Egypt with frequent irresponsible actions, usually under alcoholic influence, and diplomatic faux pas; this one was his 1ast. General Stone was left to pick up the pieces. Happily for American prestige, the next Consul General, R. Beardsley, served with distinction, helping to erase the embarrassing memories of George Butler.

40 William T. Sherman Papers, vol. 32, February 28-August 5, 1872 , Library of Congress Archives, Stone to Sherman, Cairo, July 30, 1872. 
On a different but equally difficult note, some American officers had a tendency to take Ismail's guarantee for personal satisfaction too literally. They would go to Stone and insist upon an audience with the Khedive whenever they were angered at some action. This undermined Stone's authority to a certain extent because an officer could disregard Stone and threaten to take his case directly to the Khedive. Stone usually circumvented the action, but sometimes he was forced to modify his decisions. Colonel Chaille-Long was particularly difficult on this count. When he learned that an officer who had arrived in Egypt after Chailie-Iong was going to be promoted, he threatened to write to the Khedive complaining of the injustice this promotion would represent to all of the American officers in Egypt. 41 This kind of insubordination must have given General Stone more than one headache throughout the duration of his command in Egypt. Captain Coppinger, the officer in question, was given a medal rather than the full promotion as originally proposed.

The resistance of the pashas to a centralized command, their hostility to modern education, and their lack of respect for the American officers presaged disaster for the American mission. However, if there was one man who could control the situation with all of its loose strings, it was General C. P. Stone. He possessed the

${ }^{41}$ Charles Chaille-Long, Four Continents, p. 56. 
necessary temperament required of the job, as Captain Morgan attests:

The Chief of Staff was very suave-he was not only a most accomplished man in his profession, but he was a born manipulator of men. Mott, Loring, Sibley, Kennon and several others had formed. a cabal against him, but he handled the whole crowd as though they were so many naughty children and before he got through they were tame enough to eat out of his hand and begging his influence when they wanted favors from the Khedive.

Such were Stone's talents, but they would not be enough to save the American mission from its final fate.

42 Morgan, p. 300. 


\section{CHAPTER V}

\section{THE ULTIMATE DEFEAT}

With each passing year of his reign, Ismail's financial difficulties grew substantially worse. When he came to power in 1863 the public debt of Egypt was $\exists 3,293,000$. But through his spendthrift habits and the spiraling costs of modernization, Ismail had increased the standing debt in 1876 to $E 68,110,000$, not including an additional floating debt of some E 26,000,000. As roughly computed by Lord Cromer, the future High Commissioner of Egypt, that was an average increase in the debt of $Z 7,000,000$ a year while Ismail was Khedive of Egypt. ${ }^{1}$ During the cotton boom years early in his reign, Ismail had little difficulty borrowing from the European banking houses, but after the cotton collapse the interest terms on the loans jumped to outrageous rates. One loan had to follow another in order to pay off the previous one, with the terms growing progressively worse. By 1875 the only major resource in Egypt not mortgaged was the Suez Canal. In desperation, Ismail sold his shares in the Suez Canal

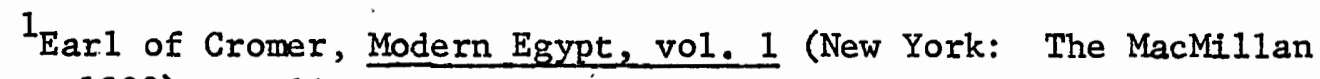
Company, 1908), p. 11. 
Company to Great Britain in November, 1875, in order to meet an upcoming interest payment. 2 To all intents and purposes, that was the end of Ismail's control over his own destiny. The four million pounds that Ismail received for his stock were not nearly enough to pay all of his bills, and it could only postpone the inevitable bankruptcy of Egypt a few months longer. Throughout those final months of financial decay, Ismail continued to make extravagant plans and spend money hoping that each new project might save him. In spite of these dreary statistics, the American-led expeditions into Central Africa continued. General Charles Gordon (who replaced Sir Samuel Baker as Governor-General of the Sudan) continued actively fighting the slave trade in the Sudan, while Werner Munzinger, now Consul for both the French and the British in Massawa was meddling in northern Abysinia. Yet throughout this period of fiscal chaos, Ismail continued to finance them all. It was not surprizing that the British and French bondholders were concerned with the situation. These imperial ventures of Ismail were costing a fortune and they were not producing a financial return, and in the meantime Ismail was about ready to default on his loan payments. Consequently, by 1875 the European bondholders were on the verge of taking control of the Egyptian treasury.

The Europeans had not been enthusiastic about Ismail's military plans from the beginning. The British and the French had watched the various

The United States Consular Despatches, vol. 11, EGYPT: Beardsley to Fish, desp. 384, December 11, 1875. 
arms orders closely, and they voiced their concern at the employment of the Americans. Initially they suspected that Ismail intended to use the American officers to help him win independence from the Sultan. In May. 1870, the French government intimated to Nubar Pasha, Ismail's Minister of Foreign Affairs, that in spite of France's 1ong-standing friendship with Egypt, she could not support this policy aimed at revolt and she would "be compelled to side with England and the rest of Europe. In the event of trouble America will be far away and it is not Egypt or the canal that will suffer, but the Khedive." ${ }^{3}$. The British, for their part, merely warned that the orders for arms placed in America were unacceptable. Lord Lyons, the British Ambassador to France, told Nubar bluntly that "if the matter were not cleared up it might create new troubles and complications which Europe did not desire." ${ }^{4}$ It is very doubtful that Ismail ever intended to openly resist the Ottoman Sultan, but the French and the British certainly let him know where he would stand if he did try.

The American officers were aware of the general European antipathy to their presence in the Egyptian army. As one officer described it, "The English are in great influence here and would like to absorb all the places of the government; the French also, the Italians and the Germans have their own cliques, and all combined would be glad to

3 Pierre Crabites, Americans in the Egyptian Army (London: George Rutledge \& Sons, Ltd., 1933), p. 44.

4 Ibid. 
see the few American officers here displaced with themselves or their countrymen substituted therefore." ${ }^{5}$ Colonel Chaille-Long claims that the British demanded dismissal of the Americans after the French catastrophe at Sedan in 1871. The British sensed that their influence in Egypt would now eclipse the badly defeated French and they assumed that the Khedive would be more sympathetic to English opinions. Nevertheless, their demands came to no avail at that time. However, the British were always sensitive to the American presence. For example, Colonel Stanton, the British Consul General in Cairo, tried to prevent Colonel Chaille-Long's appointment as Chief of Staff to General Gordon. He would have preferred another Englishman. ${ }^{7}$ In general, the Americans held their ground as long as they achieved the results they were paid to accomplish.

By 1875 the British and French apprehensions peaked. The bottom had all but fallen out of the Egyptian treasury, and there was speculation that Ismail was about ready to finance the invasion of Abyssinia, probably with the encouragement of the American officers. The rumors were rampant and factual information scarce. When asked specifically

${ }^{5}$ The Henry C. Derrick Letters, 1875-78, in private possession, Derrick to Derrick, 非, February 23, 1877.

${ }^{6}$ Charles Chaille-Iong, My Life on Four Continents, vol. 1 (London: Hutchins on \& Company, 1912), p. 41. Chaille-Long states that had it not been for the persuasion of the Russian Consul General's wife, the American mission would have been dismissed at that early date.

${ }^{7}$ Ibid., p. 70. 
by Lord Vivian, the British acting Consul in Alexandria, whether he intended total conquest of Abyssinia, Ismail denied any such intention. He merely wanted to live in peace with the Abyssinians, but it seemed that this was not possible as long as they continued to raid the peaceful fellahin villages along their mutual border. 8 However, the European diplomats viewed the growing Egyptian involvement in Abyssinia as part of the total imperial scheme for expansion in Africa and the latest development in a long history of Egyptian expansion in the area. The roots of this current conflict between Egypt and Abyssinia in mid-1875 date back to the reign of Muhammad Ali. However, Ismail did not take an interest in this area until May, 1865, when the ports of Suakin and Massawa on the Red Sea were once again ceded to Egypt by a firman from Sultan Abdul Aziz. 9 An 1866 firman granted to Ismail additional land surrounding the two ports. ${ }^{10}$ The British watched Ismail's expansion carefully and they might not have allowed this Ottoman administrative transfer had it not been for Ismail's solemn promise to abolish the thriving slave trade of the ports. The Sultan acquiesced

${ }^{8}$ Georges Douin, Histoire du Règne du Khédive Ismaïl, Tome III, $2^{\mathrm{e}}$ Partie, (Rome: Societe Royale de Geographie d'Egypte, 1936), pp. 417-18.

${ }^{9}$ M. Abir, "Ethiopian-Egyptian Border Problems," Journal of African History 8(1967), pp. 443-461.

$10_{\mathrm{E}}$. R. Turton, "Kirk and the Egyptian Invasion of East Africa in 1875: A Reassessment," Journal of African History 11(1970), p. 357. 
to the arrangement for the rather considerable sum of $€ 25,000$ Egyptian (the original rental paid by Muhammad Ali) plus another $€ 7,500$ Egyptian or $\exists 32,500$ Egyptian annually. ${ }^{11}$ With this move Ismail controlled the Egyptian side of the Red Sea. He also blocked Abyssinian access to the sea, a situation the Abyssinians were not going to accept quietly. Fortunately for Ismail, internal conflicts in Abyssinia prevented any immediate reaction to the Egyptian occupation of the port cities.

In January, 1872, the Ras (chief) of Tigre in northern Abyssinia was crowned King John and the situation changed abruptly. ${ }^{12}$ Ismail had taken advantage of the Abyssinian disunity during the seven years since the 1865 firman and he had actively pursued Egyptian hegemony along the Red Sea littoral to the Gulf of Aden. In 1870 the Egyptian naval squadron was stationed in the area to cruise along the coast from Suakin to Cape Guardafui. ${ }^{13}$ In 1872 with a comparatively unified Abyssinia behind him, King John intended to win back Abyssinian access to the sea. ${ }^{14}$ Using the territory of Bogos as his base, the king began his campaign by haras-

11 Georges Douin, Histoire du Règne du Khédive Ismaïl, Tome III, $1^{\text {re }}$ Partie (Rome: Societe Royale de Geographie d'Egypte, 1936), pp. 276-77.

${ }^{12}$ John Marlowe, Spoiling the Egyptians (New York: St. Martin's Press, 1975), P. 136.

$$
{ }^{13} \text { Ibid., p. } 137 .
$$

${ }^{14}$ Abyssinia, in the second half of the nineteenth century, was divided into a series of semi-independent kingdoms which claimed at least a marginal allegiance to the "King of Kings." There were three 
sing the Egyptian fellahin living along the Egyptian-Abyssinian frontier. Raiding parties pillaged the small villages and farms. King John's army was poorly armed and disciplined but highly motivated and courageous when there was booty to be taken. The border situation was not to be tolerated and in his letter of March 3, 1872, Ismail laid out his plan for the invasion and conquest of the territory of Bogos to Munzinger Pasha. ${ }^{15}$

Munzinger was to send an ultimatum to King John and if he failed to desist, which Ismail fully expected, Munzinger was to occupy Bogos. ${ }^{16}$ Munzinger Pasha agreed and he left Suez on Apri1 4, 1872, with 800 men and the required supplies to conquer Bogos. ${ }^{17}$ By late June, the Egyptian troops with their superior weapons had completely subjugated the small territory, and Munzinger Pasha was installed as the military

claimants to this title upon King Theodore's death in 1868. John IV, the Negus of Tigre, was not able to assume the title until 1872 after displacing his first competitor, Tikle Georgis. Menelik II, the Negus of Shoa, John's second rival, prudently chose to accept John's claim. Menelik concentrated his interest to the south and east while King John antagonized the Egyptians in the north. Abyssinia was united on the surface, but the rivalry between these two men was intense. Upon King John's death in 1889, Menelik became the "King of Kings." He truly united Abyssinia and maintained its independence in the face of the nineteenth century European colonialism in Africa.

$$
\begin{aligned}
& 15_{\text {Douin, }}{ }^{\mathrm{e}} \text { Partie, p. } 338 . \\
& 16_{\text {Ibid. }} \\
& { }^{17_{\text {Ibid. }} \text { p. } 340 .}
\end{aligned}
$$


governor in Keren, the capital of Bogos. 18 Ismail explained his actions in Bogos to the European and American diplomats by pointing to King John's predatory intrusions and by guaranteeing a more peaceful existence for the native inhabitants. Furthermore, he theorized that it was Egypt's mission in the modern world to civilize Africa. He would build a railroad from upper Egypt to Massawa and it would have to go through Bogos; however, Ismail disavowed any further interest in the Abyssinian territory. King John was left to bide $h$ is time and to plan his retaliation.

Ismail's next move was the occupation of Berbera, a port in the Gulf of Aden, in 1873. 20 This venture brought him into direct conflict with the British interests in the area. In the past, the British Resident of Aden had kept a close watch on the events and affairs in Berbera, but the Egyptian expansion imperiled British prerogatives. In August, 1875, an agreement between the Khedive and Consul General Stanton cleared up the situation. The Sultan, accordingly, issued a firman on July 5, 1875, ceding the ports of Zeila and Berbera to Ismail for the tribute of $€ 15,000$ a year. 21 The convention drawn up the following month between Egypt

18 United States Consular Despatches, vol. 6, EGYPT: Beardsley to Fish, desp. 19, October 16, 1872 .

19 United States Consular Despatches, vol. 7, EGYPT: Beardsley to Fish, desp. 46, December 12, 1872.

20 Marlowe, p. 138.

${ }^{21}$ United States Consular Despatches, vol. 10, EGYPT: Beardsley to Fish; desp. 337, July 17, 1875 . 
and Great Britain allowed Ismail virtual control of the African coast 22

as far as Cape Guardafui. The British once again bowed to Ismail's plans on the guarantee that an active campaign would be waged against the slave trade.

Moving farther to consolidate his position in Africa, Ismail ordered Raouf Pasha to Zeila on July 16, 1875, to become the Maamour (comander of the troops) of the city, and he further instructed him to establish a secure route for the lucrative trade caravans coming from Harrar. In secret, Raouf Pasha was ordered to take Harrar but to cover his movements by stating he was looking for the sources of the Sobat River, in case the British were curious. 23 Raouf Pasha with 1,200 troops captured the walled city of harrar with little opposition on October 11, and word was sent to the European and American consuls that the King of Harrar had obstructed the free passage of the caravans, hence the necessity for Egyptian control of the city of Harrar. 24 Naturally King John was upset; first Massawa, then Bogos and Berbera. Now Zeila and Harrar were occupied by Ismail's forces. A glance at a map of the area amply illustrates the extent to which

22 Turton, p. 358.

23 Georges Douin, Histoire du Règne du Khédive Ismaïl, Tome III, $3^{\mathrm{e}}$ Partie, facs, A (Rome: Societe Royale de Geographie d'Egypte, 1936), p. 602 .

${ }^{24}$ Charles P. Stone, "The Political Geography of Egypt," Journal of the American Geographical Society of New York 15 (1884), p. 369 . 
Abyssinia had been encircled. During the summer of 1875, King John began his counter-move. Rumors of his gathering forces soon reached Cairo. It appeared that his army was being assembled on the northern frontier of Abyssinia and readied for the invasion of Hamesin, a buffer 25

state between the two powers. In early August he attacked 30,000 strong and by late September the army was a sixteen hour march from Massawa. ${ }^{26}$ Ismail was determined that this threat should be met. An air of secrecy surrounded the entire Abyssinian campaign. Colonel Chaille-Long, the initial choice for commander of the expedition was recalled from furlough in France to take comand, only to be replaced. at the last minute by a Danish officer, Colonel Arendrup. ${ }^{27}$ Major Durholtz, a Swiss officer, did not recelve the details of his assignment until he left Cairo, while Major James Dennison, a former second lieutenant in the Union Army, was awakened in the middle of the night and told to report that very morning prepared to leave for Massawa. ${ }^{28}$

25

United States Consular Despatches, vol. 11, EGYPT: Beardsley to Fish, desp. 364 , November $26,1875$.

${ }^{26}$ Ibid.

27 William McE. Dye, Moslem Egypt and Christian Abyssinia (New York: Atkins and Prout, 1880; reprint ed., New York: Negro Universities Press, 1969), pp. 130-31.

${ }^{28}$ Charles Chaille-Long, Four Continents, p. 174. Arendrup's wife, according to Chaille-Long, appealed to Nubar Pasha, President of the Council of Ministers, to allow her husband to be commander of the expedition. 
The expedition consisted of 2,500 men armed with Remington rifles, two six-gun batteries of mountain howitzers, and six rocket stands. 29 This small but well-armed force was considered more than adequate to meet and humiliate King John's motly force.

Simultaneous with the departure of Arendrup's expedition to Abyssinia, Munzinger Pasha was ordered to lead a force of some 600 men Into the Shoa country and join with King Menelik's forces. 30 It was believed that Menelik, who was fueding with King John, would be willing to attack the Abyssinian king on his southern frontier, thus forcing him to divide his forces and guaranteeing the Egyptians an easy victory. On his arrival in Massawa; Arendrup dispatched a letter to King John stating that his orders were to secure the Egyptian border and to collect an indemity for the damage perpetrated by the Abyssinian raiding parties. 31 when no answer arrived, Arendrup boldly advanced into the Hamasin territory, too boldly.for his own welfare. Colonel Lockett summarized the disaster that occurred in the following concise manner:

n. .. He (Arendrup) advanced with foolhardy confidence into the heart of the enemy's country, was deceived and betrayed by the Governor of Hamasin, was enveighed by superior strategy into

\section{William Loring, A Confederate Soldier in Egypt (New York:} Dodd, Mead \& Company, 1884), p. 301.

${ }^{30}$ Samuel Lockett Papers, "Notes on the Abyssinian Camaign," Southern Historical Collection, University of North Carolina.

31 Loring, p. 302 . 
the valley of the march, and was completely surrounded by an overwhelming force of the Abyssinians. And when his little army was attacked on all sides, his men instead of fighting like soldiers, huddled together like sheep and fired a short time in the air, and then stood and allowed themselves to be mowed down like grain before the reaper's blade. The whole party with the exceptions of a few outposts, rear guards and reconnoitering parties was demolished in about one hour as reported by an Englishman in King John's army. 32

Arendrup had ignored every standard military precaution possible on his disastrous march inland. When General stone realized that Arendrup had advanced over one hundred miles from his base of supplies, he sent orders for the Dane to halt and fortify his position and to await reinforcements. ${ }^{33}$ Whether the order reached the comander or simply arrived too-late is not known, but even without word from Cairo, Arendrup had been warned of his danger. Major Dennison, an experienced officer, recognized the precariousness of their position. According to General Loring, Dennison "begged" Colonel Arendrup not to endanger the mission by entering an unknown valley deep into the enemy's country without even locating the enemy's position. ${ }^{34}$ Arendrup persisted in his course; however, he did accept Dennison's alternative suggestion

32 Lockett, "Notes." General Kirkham, a renegade English soldier who served without distinction under Gordon in China, was the selfappointed advisor to King John's army. He was detained in Massawa in December, 1875, by General Ratib Pasha while on a consular mission for King John. He provided accurate and detailed information on the Abyssinian army; however, the Egyptian commander did not trust the source and Kirkham's warnings went unheeded. He died shortly thereafter, a prisoner of the Egyptians.

${ }^{33}$ Loring, p. 301.

${ }^{34}$ Lockett, "Notes." 
to fortify their rear. On November 18,1875 , the day of the disastrous battle of Gundet, Dennison and his small company were stationed on a plateau five or six miles back, to protect the rear and man two pieces of mountain artillery. They did not learn of the battle until retreating stragglers, who were badly wounded and mutilated, reached the small camp a day later. 35

At first, Dennison was determined to stand and fight. However, upon learning the scope of the catastrophe and finding that his men refused to continue holding their position, he had no choice but to reconsider his decision. The retreat plans were organized quickly after the arrival of a letter from King John demanding their surrender. Dennison sent a reply designed to stall for time, and the men spiked the cannons and slipped out of camp. At Khaya Khor they met up with Major Raif and his company, who like themselves had been assigned elsewhere during the battle. The reunited forces then retreated to Massawa to bring the terrible news of defeat. 36

The Munzinger expedition met a similar fate. He and his men were betrayed and murdered by their guides near Lake Aussa in Galla country, on November 15, only three days before Arendrup met his death. One smal1

${ }^{35}$ Loring, p. 304 .

36 Lockett, "Notes." 
company led by an alert native officer retreated, fighting most of the way to ultimately relate their harrowing tale. 37 News of this disaster reached Cairo in mid-December, but by that time major retaliatory action was already underway.

The Egyptian government tried unsuccessfully to prevent news of the Arendrup disaster from becoming public for fear of its effect upon the Egyptian finances and prestige. But less than two weeks after the annihilation, the American Consul General Beardsley, sent a dispatch with the news and the prediction that this defeat would have unfortunate political and financial effects. ${ }^{38}$ The financial situation was about to break wide open even without a military disaster like this to emphasize the Egyptian problems. Ismail had just finished selling Egypt's last major resource, the Suez Canal shares. If he did not retaliate immediately as commonly expected, the true condition of his government's coffers might be suspected. He had to react quickly to forestall the discovery of his impending bankruptcy. General Stone also wanted to retaliate quickly, although for a somewhat different reason. His revitalized army had just taken a tremendous beating and the American prestige was at stake. Perhaps he saw this as an open opportunity to display the superiority of modern organization and technology versus

\section{Ibid.}

${ }^{38}$ United States Consular Despatches, vol. 11, EGYPT: Beards ley to Fish, desp. 381, December 1, 1875. 
the traditional pasha system. 39 With Ismail and Stone agreeing upon the necessity of immediate action, planning for a second expedition began.

General Stone immediately set the Third Section in action making maps for the expedition. He had received a communique with specific, first-hand descriptions of the territory that had to be analyzed and compiled from Father Duflot, a Jesuit priest who worked in the area. 40 The strategy and logistics of the campaign were worked out in advance by General Stone, Prince Hussein, the Minister of War and their staffs with consultation with Ismail and his cabinet. The first confrontation between the Americans and the pashas arose over the selection of the commander for the expedition. General Stone suggested General Loring as the most experienced man available. He received the tacit support of Ismail and the active support of the Minister of Foreign Affairs, Nubar Pasha. Consequent1y, General Loring was ordered to report to Cairo immediately to take command of the expedition. On his arrival, however, Loring was informed that he would be the Chief of Staff and second in command to General Ratib Pasha.

The cabinet ministers felt that the chief in command ought to be a Muslim and Nubar Pasha (a Christian Armenian) was prevailed upon to

${ }^{39}$ This is the theory of both Pierre Crabites and William Hesse1tine the only two scholars to publish a book on the American mission to Egypt.

${ }^{40}$ Lockett, "Notes." 
agree. Ratib Pasha, a close friend of Sherif Pasha the current Prime Minister, was selected as the commander. ${ }^{41}$ Almost as if to counter this first defeat, General Stone assigned virtually every European and American Staff officer he had to the expedition: Colonel William Dye, Colonel Charles W: Field, Lieutenant Colonel Henry Derrick, Lieutenant Colonel Mocklin, a Swiss officer, Major Charles F. Loshe, Major Robert Iamson, Major Duller, a Belgian officer, Surgeon Major W. W. Wilson, Surgeon Major Thomas D. Johnson, Captain Sormani, an Italian, Captain David Porter, and Captain Henry Irgens. Later Lieutenant Colonel Charles Graves and Colonel Samuel Lockett were added to the roster. 42

In the final planning days, the commanding officer, Generals Ratib and Loring, and Colonels Dye and Field were summoned to three separate meetings with the Khedive, General Stone, and Nubar Pasha to be briefed and to make their own suggestions. The military features of the country were discussed and all other elements that pertained to the campaign were finalized. ${ }^{43}$ There seems to have been a feeling among the American officers that they ought to have been more closely consulted. However, they accepted the plans with only a few suggestions. 44

$$
\begin{aligned}
& { }^{41} \text { Loring, p. } 333 . \\
& { }^{42} \text { Lockett, "Notes." } \\
& 43 \text { Dye, p. } 155 . \\
& { }^{44} \text { Loring, p. } 335 .
\end{aligned}
$$




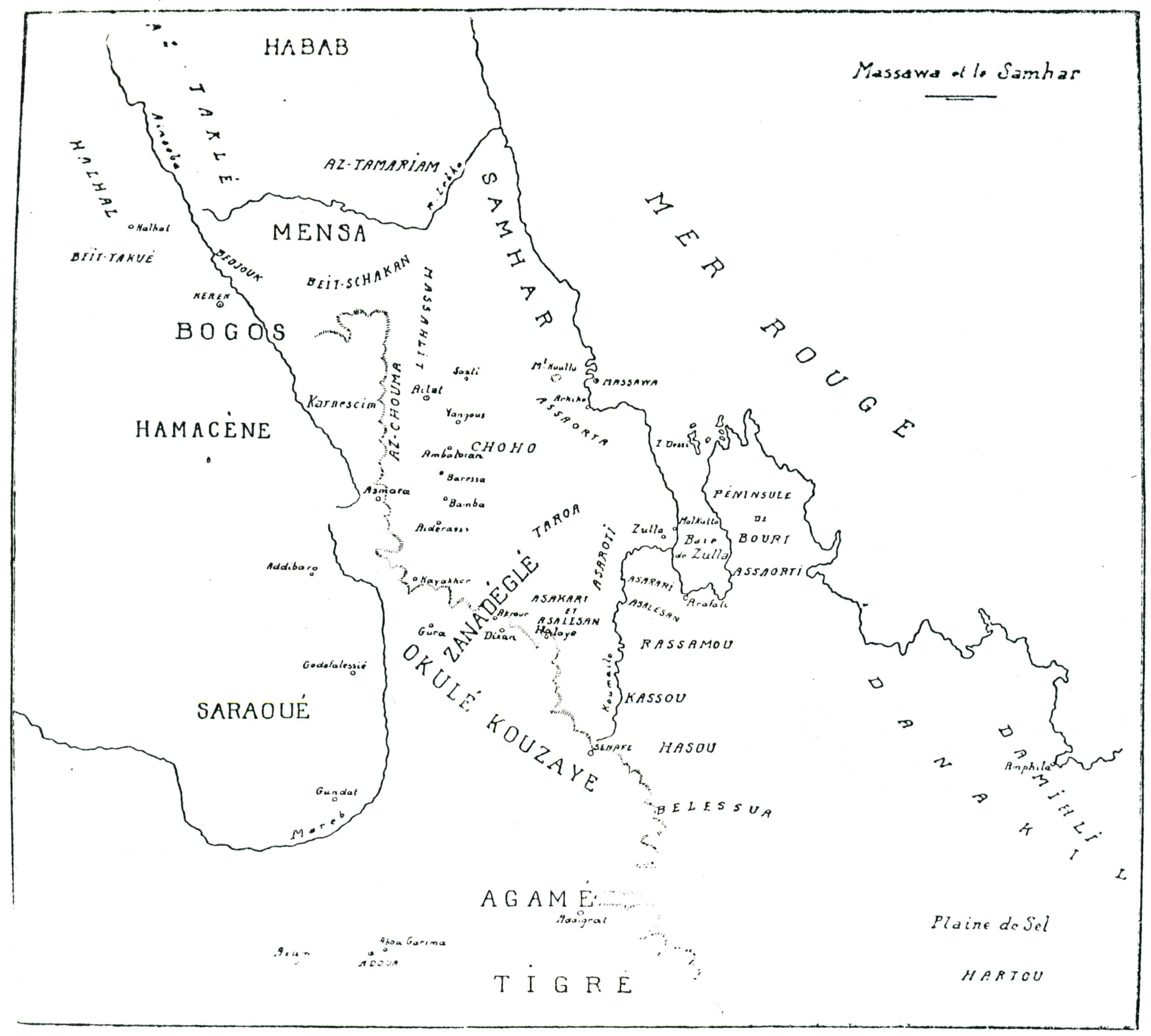

George Douin, Histoire du Règne du Khédive Ismail, vol. 3, Part 2, plate $\mathrm{X}$. 
Colonel Dye was particularly concerned about the insufficient plans made for their transportation into the Abyssinian interior.

At the meetings the men were also briefed as to the political and military objectives of the expedition. Ismail made it very clear that the purpose of this campaign was to punish King John. 45 They were to advance until either they engaged the Abyssinians in battle or captured King John's capital, Adua. Nubar Pasha, on the other hand, was adamant that the expedition be carried out quickly (before the beginning of the rainy season), and upon their successful conclusion they must evacuate the area and return to Cairo immediately. 46 It was to be fully evident that Muslim Egypt had no plans for annexing Christian Abyssinia in part or in its entirety. Nubar Pasha was quite certain that Europe would not allow more than a brief foray into Abyssinian territory, and he wished to avoid any additional complications. With the organization complete, Ismail placed Ratib Pasha's hand into General Loring's hand as a symbol of fraternity and asked that both men work together in harmony, specifically noting that Ratib should pay heed to all of Loring's suggestions. 47 The bulk of the staff officers and the troops (variously estimated at between 16,000

45 "Egyptian Campaign in Abyssinia," Littel's Living Age, 5th Series, 19 (July-September, 1877), p. 280.

46 Loring, p. 330; and Dye, p. 158.

47 Loring, p. 333. 
and 20,000 men) left by steamers from Suez for Massawa on December 6, $1875 .^{48}$ Upon arrival in Massawa some two weeks later, the base camp for the expedition was set up. That was to be just about the last thing General Loring and Ratib Pasha were to agree upon. The most important portion of the account of the Abyssinian campaign was not the actual battle between the two warring countries but rather the less physical but equally fierce conflict between the traditional pashas and the American officers. In fact one can blame the less than satisfactory results of the Abysinian campaign on the general lack of coordinated action between the commanding officers, General Ratib Pasha and General Loring.

The problems of General Loring fell into four interrelating categories; authority, language, transportation, and communications with Cairo. The first problem, authority concerned the existence of two staffs: Lorings's official staff and Ratib's secret.staff. Immediately upon his arrival in Massawa, Loring set about establishing his staff on a modified plan of the general staff in Cairo. The various foreign staff officers, once assigned their duties, went to work only to find someone else had been ordered to do their job, or more often, they found a native officer doing exactly the opposite of their own orders. For example, Lieutenant Colonel Mocklin was to be the assistant Inspector 
General, and he was charged with the duty of inspecting the supply trains to verify that the goods sent into the interior matched the orders. He soon found that his orders from Loring were nearly opposite his native co-officer's orders from Ratib Pasha. ${ }^{49}$ Ali Bey, (an Italian officer who had converted to Islam) was assigned as Chief of Ordnance, but he found he could only watch over the ordnance stores. He had no. power to prevent each commander from appropriating his private stocks. After a few weeks of this chaos, Ali Bey could stand the frustration no longer and an Arab officer was assigned as his replacement. 50

Such incidents appeared regularly. Major Losche, assigned to the Quartermaster section, went out into the countryside in search of supplies only to find Ratib's officers had already done so. Lieutenant Colonel Derrick found the same kinds of obstructions on the engineering side of the camp. 51 Ratib Pasha's personal staff worked independently of General Loring and his staff; hence, the confusion and delays were considerable and chronic. To make matters worse, General Loring's orders were generally ignored or at least disputed unless Ratib Pasha's seal was prominantly displayed on the papers. Colonel Dye, head of the administrative section, complained that even after jointly issuing

$$
\begin{aligned}
& { }^{49} \text { Lockett, "Notes." } \\
& 50_{\text {Dye, p. } 173 .} \\
& 51_{\text {Ibid., p. } 174 .}
\end{aligned}
$$


an order with General Loring, Ratib Pasha would nearly always send a conflicting order on the same topic to his personal staff. 52 Loring would confront Ratib Pasha with the evidence, and the pasha would be penitent and promise to consult his Chief of Staff in the future, only to send a new set of private orders the next day.

Loring believed that this obstructive behavior represented the pashas' opposition to the entire campaign. He claimed that Ratib Pasha, Osman Pasha, and the other high ranking native officers were doing their best to prevent this campaign from ever succeeding. Loring blamed this attitude upon a combination of cowardice, apathy, and unwillingness to openly disobey the Khedive. 53 Loring's opinion aside, there was another reason for the apparent obstruction or misinterpretation of the orders. General Loring's colorful English lost much of its meaning in his frantic attempts to translate his orders into French and/or Arabic. General Ratib, for his part, spoke only a modicum of French and between the two men the communication gap was insurmountable. 54

Interpreters on both staffs did exist. However, both Loring and Dye, the two men who wrote of their Abyssinian experiences, disclaim any competence on the part of these linguists. Dye credits only one man, Major Fritz Thurnheyssen, an Austrian who was fluent in six

$$
\begin{aligned}
& 52 \text { Ibid., p. } 218 . \\
& 53 \text { Loring, p. } 343-344 . \\
& 54 \text { Loring, p. } 344 .
\end{aligned}
$$


languages, as capable. Unfortunately he goes on to state that Thurnheyssen was a snob and one of Ratib's cohorts which did not inspire any confidence among the officers of the general staff. 55 The lack of adequate interpreters meant that all orders to the line had to be written and translated into Arabic, French, Turkish, and English. Colonel Dye's section was supposed to handle this duty, but he claims that he was so understaffed that any staff officer who happened to walk past the tent was conscripted for ten minutes to an hour to help copy the documents. 56 This situation could only add to the already considerable communications problem.

The third problem area concerned the transportation of this massive army over the Abyssinian mountains into the relatively unmapped and unknown enemy country. Dye had complained of the transportation plans while still in Cairo, and he had been assured that the necessary drivers, animals, and carts would be supplied. However, the worst of his fears came true. After one month in Massawa scrounging for any animal with four feet, the expedition counted forty-four elephants, 600 carts, and 2.,000 camels or approximately twenty percent of the promised transportation needs for an army of 16,000 to 20,000 men. 57

$$
\begin{aligned}
& { }^{55} \text { Dye, p. } 167 . \\
& { }^{56} \text { Ibid., p. } 176 . \\
& { }^{57} \text { Dye, p. } 205 .
\end{aligned}
$$


In order to reach the interior and complete their mission before the rainy season, they had to start regardless of the transportation shortage. Obviously the shortage hindered their progress considerably, and it meant that all unessential baggage had to be left behind.

The final problem concerned the written communication difficulties the Americans experienced in sending their messages and mail to Cairo. Apparently soon after their arrival in Massawa, one of the Americans criticized General Ratib in a letter home and word of his remarks leaked to the public. In turn, Ratib Pasha received word from his friends in the Khedive's court of this criticism. The next thing General Loring knew an order from the Khedive arrived requiring all correspondence from the forces to be censored. 58 This order included both unofficial and official messages. The Americans were furlous, especially when the order was later modified to allow the native officers the privacy of sealing their letters. This action left the Americans fuming at the blatant favoritism towards the pashas. Eventually General Loring obtained permission to communicate with General Stone privately, but the American officers were not allowed to write home in privacy throughout the campaign. The magnitude of this problem became painfully apparent at the unsuccessful conclusion of the expedition when the American officers found themselves isolated and without the means of communication to tell their side of the story. 
General Ratib Pasha, for his part, had some legitimate complaints to lodge against General Loring and his staff. With the language problem being what it was, he felt that his native staff was necessary in order to accomplish all the needed work for the campaign. Ragab Sadik, a native officer kept an interesting and informative journal of the campaign. His January 18, 1876 entry alludes to the 1inguistic difficulties of the Arab commanders. Since the staff officers did not know Arabic, the orders from Ratib were often referred to the lower ranking native officers of the general staff. Those men were supposed to communicate the orders upward to the foreign staff officers. 59 It is clear that this was not always happening and the resulting discord contributed substantially to the ensuing disaster.

General Ratib Pasha also had a better sense of the capabilities of the rank and file fellah. General Loring was a blustery American Indian fighter whose concepts of warfare were aggressive and left little room for hesitation. The Egyptian troops on the whole were not used to fighting, and they were extremely jittery. King John had liberated scores of mutilated prisoners for the green Egyptian troops to witness. Understandably, they were not excited about meeting the King's army. These men needed to gain some confidence, but General Loring's

5 Georges Douin, Histoire du Règne du Khédive Ismäil, Tome II, $3^{\mathrm{e}}$ Partie, facs. B (Rome: Societe Royale de Geographe d'Egypte, 1941) p. 872 . 
enthusiasm for battle did not allow for this aspect of the Egyptian temperament. Ratib Pasha would have preferred to meet the enemy on his own terms, from a fortified position in a fort. When immediate victory did not come to the Abyssinians, the army would begin to disintegrate and the Egyptian troops, with a new sense of confidence, would have been ready to fight. ${ }^{60}$ Unfortunately, either Loring was not listening to Ratib's reasoning or he did not understand it.

The third problem for Ratib Pasha was identical to Loring's; that of authority. Just as Loring's orders were disputed and ignored by the natives, General Ratib felt that his orders were often disputed and ignored by the European and American staff officers. To make matters even worse, Prince Hassan, the third son of Ismail, showed up ostensibly to gain some experience and to serve as the nominal Commanderin Chief above Ratib Pasha. Prince Hassan had studied in England and was fluent in English, French, and German, as well as his native languages of Arabic and Turkish. He had been recalled from serving as an honorary subaltern officer in the Prussian Cavalry service to accompany the Abyssinian expedition. Ratib welcomed the Prince, but he soon found that Ismail's son, with his European education often sided with the general staff decisions over his head. ${ }^{61}$ Hence, the command was further

${ }^{60}$ Lockett, "Notes."

61 Ibid. 
split and the inconsistencies abounded. Under these circumstances, the Abyssinians were, at times, the least of the expedition's enemies. Ironically, one of Ismail's purposes for sending Prince Hassan was to keep peace between the two generals. Word of their dissension had come back to Cairo, and he sensed that peace between the two men was vital to the success of the mission. If the campaign turned into a failure it would not only destroy the American reputation in Egypt but it would probably complete the disintegration of his power. Ismail believed that this dissension was the work of someone, and he secretly ordered Hassan, in a letter dated January 23, 1876, to find and report the culprit to him. 62 Hassan wrote back to his father on February 17 assuring him that harmony existed between the general staff and Ratib. 63 It seems that all three of the major commanders were on entirely different wave lengths.

In the end no one strategy prevailed, and the campaign was a disaster. The Egyptian forces met the Abyssinian army in a half-way position on March 7, 1876 on the plain of Gura. Loring had wanted the troops from Fort Gura to join those at Khaya Khor; thus a united army would meet King John's forces head on with the additional advantage of a dominating position from above the valley. General Ratib wanted the forces to stay

62 Douin, facs. B, pp. $872-873$. ${ }^{63}$ Abdin Archives, Periode Ismail, doss. 9/1, February 17, 1876 , Hassan to Ismail. 
in their respective forts and to fight a defensive battle at first. Instead of either strategy, the troops were ordered to leave. the security of Fort Gura, but they never joined up with the forces at the Khaya Khor sumit. ${ }^{64}$ The split command and split forces met a united Abyssinian army. The battle did not last long due to a sudden and spontaneous retreat initiated by the Egyptian soldiers. Neither the American nor the native officers could halt this march to the fort. The major casualties occurred as a result of the disorganized retreat and from the Abyssinian slaughter of Egyptian prisoners. The following day the Abyssinians laid siege to the fort; but due to lack of experience with siege warfare, the Abyssinian army grew discouraged, and communications were soon underway for a truce. ${ }^{65}$

The recriminations that followed were almost as bloody as the battle itself. The American officers felt that the native officers, most particularly General Ratib Pasha, had not followed the Khedive's instructions to heed General Loring's advice and that his failure to cooperate was the primary cause of the poor performance of the Egyptian troops. The American officers were not pleased with the results of the campaign to be sure, but on the other hand, most of them had witnessed

${ }^{64}$ Abdin Archives, Periode Ismail, doss. 9/1, March 22, 1876. Loring to Stone.

${ }^{65}$ Lockett, "Notes." 
far worse military disasters. The Egyptian forces had not even come close to soundly defeating King John's army, but they were still in possession of the territory as far as they had advanced. 66 The casualty figures 1ikewise were inconclusive in the American eyes. General Stone reported a loss of 1,800 men while Colonel Dye put the figure closer to 3,300 men. 67 In general, the Americans did not see the Abyssinian campaign as an unmitigated disaster, and the officers felt that as soon as the American story of the campaign (ie. the incompetence and cowardice of the native officers) was made known to Ismail, the Khedive would allow them to return to fight the battle their way. Unfortunately, the American officers were never given the opportunity to relate their version of the story much less were they allowed to resume the campaign.

This less-than-decisive campaign could not have come at a worse time for Ismail, because on April 8, 1876, the financial crisis came to a head. 68 On that day the Khedive was forced to suspend the payment of his treasury bills. From that point forward, Ismail was primarily concerned with maintaining his position as Khedive and undisputed ruler of Egypt. In this critical hour, Ismail was not interested in listening to lame excuses from his American officers. He needed all the support

${ }^{66}$ Derrick, Letter 26, Cairo, July 28, 1876.

67 William T. Sherman Papers, vol. 44, June 3-October 30, 1876 , Library of Congress Archives, Stone to Sherman, Cairo, July 13, 1876. 68 Cromer, p. 68. 
he could muster from his pashas to prevent the complete inundation of his government by the outraged bondholders of Europe.

In the Abysinian campaign the much acclaimed American technical prowess had proven useless as long as the traditional pashas were still in ultimate control of the situation. Half-way measures had not worked, but Ismail was no longer sufficiently secure in his position to give the Americans full command. Moreover, he did not want to accept the consequences of his own vacillation between the pashas and the Americans. The American officers and their highly trained army were sent to humiliate King John and they failed. Ismail was not used to failure in his imperial ventures, and as EII E. Farman, the newly appointed American consul suggests, one would be relying too much on the good nature of an oriental potentate to suppose his good humor under the current circumstances. 69 The American officers found themselves isolated and unable to reach the Khedive for redress as they had in the past. Obviously the last vestiges of Ismail's support were gone.

The staff officers were ordered back to Massawa soon after the battle, but they were not allowed to contact anyone in Cairo, not even

${ }^{69}$ Eli E. Farman, Egypt and Its Betrayal (New York: The Grafton Press, 1908), p. 195; and United States Consular Reports, vol. 8, EGYPT: Beardsley to Fish, desp. 45, December 11, 1872. Beardsley notes Ismail's displeasure at the premature reports of Sir Samuel Baker's failure to subdue the slave traders in the Sudan. Baker eventually succeeded in his task, the American officers did not. 
their families. The Governor of Massawa, the young nephew of Sadik Pasha, Ismail's notorious Finance Minister, controlled the telegraph facilities and he naturally assumed that the Khedive would want all news of the catastrophe contained. Hence, he effectively silenced any American stories by placing the telegraph office off limits to the American officers. ${ }^{70}$ Several of the engineering officers received orders to map portions of the surrounding districts, but the majority of the officers were left idle in the stifling heat of Massawa. While the main portion of the native troops were sent back to Cairo in April, the Americans were not allowed to return to the capital until late June.

When they arrived in Cairo, they found their political and social position in the Egyptian government service drastically altered. The American officers were now shunned, and they did not receive their normal courtesy reception in court by Ismail. During the months of their absence a complete shift in power had occurred. Nubar Pasha, the western oriented Foreign Affairs Minister, had been dismissed at the beginning of the year and the traditional pashas were now in full control of the government.

With the more traditional forces in power, the Americans were not surprized to learn that the size and scope of the disaster had been greatly exaggerated, and of course, the staff officers were entirely at fault for

70 Dye, p. 447. 
the Abyssinian fiasco. The foreign press corps did not help matters either. With their aid, the rumors that proliferated in Cairo were soon rampant in Paris and London. 71 One report even claimed that Prince Hassan had been captured by King John. Since the Egyptian polfcy was to refrain from any official comment on these speculations, the European newspapers published these rumors circulating in Cairo as fact.

In contrast to the American experience, the Turkish, Circassian and Arab officers who returned to Cairo directly from the campaign were wel1 received in court. Virtually every native officer received a.promotion or high decoration for his performance in Abyssinia. Many of the men deserved the promotions but the American officers were infuriated that the blatantly obstructionist officers, among them General Ratib Pasha, also received promotions. ${ }^{72}$ Emperor Wilhelm of Prussia honored Prince Hassan with a complimentary promotion to Major in the Prussian cavalry, however the prince never returned to accept the award because his father, Ismail had an even greater promotion for Hassan as Commanderin-Chief of the entire Egyptian army. ${ }^{73}$ The American officers and those native officers assoclated with the general staff did not fair as well. After more than a year of negotiating, General stone procured minor

$$
\begin{aligned}
& 71 \text { Sherman Papers, vol. 40, Stone to Sherman, Cairo, July 13, } 1876 . \\
& 72 \text { Dye, p. } 483 . \\
& 73 \text { Ibid., p. } 484 \text {. }
\end{aligned}
$$


decorations for all the Americans who participated in the campaign, but they did not consider that concession as equal treatment.

In addition to the shift in power within the government and the poor press coverage that the Americans were subject to, a third factor played a role in their unpopular reception. Their chief spokesman and concilliator, General Stone was no longer privy to Ismail's inner staff. Throughout his twelve years as Chief of Staff, he had been permitted daily access to the Khedive. ${ }^{74}$ Now he found that any access at all was difficult to arrange. The Master of Ceremonies would give General Stone the wrong hour for his scheduled appointment with the Khedive. Stone would either arrive late, much to the displeasure of Ismail or he would miss the conference altogether. ${ }^{75}$ Without these conferences, Stone's effective council in military matters and in respect to the American officers was greatly diminished. ${ }^{76}$

As if dealing with the traditional pasha system was not enough of a problem, Stone found his authority under attack from the Europeans in Ismail's court as well. General Charles Gordon, the British GovernorGeneral of the Sudan, apparently encouraged by the ever calculating British authorities in Cairo wrote a letter to General Sherman describing

$$
\begin{aligned}
& { }^{74} \text { Dye, p. } 489 . \\
& { }^{75} \text { Ibid., pp. } 488-489 \text {. }
\end{aligned}
$$

${ }^{76}$ In fact it is questionable whether stone had any influence at all by that time over the fate of the American mission. His personal friendship with the Khedive may have been the only factor at work in regards to the eventual decoration of the officers. 
the conditions that the American officers were enduring as unbearable. He even suggested that General Sherman himself come to Egypt for a visit to observe and help rectify the situation. After mailing the letter, Gordon showed a copy of it to General Stone. Rather astonished at Gordon's interference, Stone answered all the charges in the letter and Gordon apologized and requested that Stone inform General Sherman of his mistake. Stone felt that any further outside interference would only hurt the position of the officers more. Besides, they could always resign if they felt that the situation was intolerable. Stone believed that this aggravating episode had been instigated by the British with the intention of forcing the Americans out of Egypt. ${ }^{77}$

One of the difficulties described by General Gordon was the fact that none of the American officers (including Stone) had been paid since prior to the Abyssinian campaign. Needless to say, by September their financial situation was desperate. Even those officers who had saved a portion of their salaries regularly began to feel the pinch. ${ }^{78}$. After ten months without pay, an order was finally given to dole out one" month's pay for the men. ${ }^{79}$ From October, 1876, to their ultimate dismissal in June, 1878, paydays resumed on an irregular basis. The final

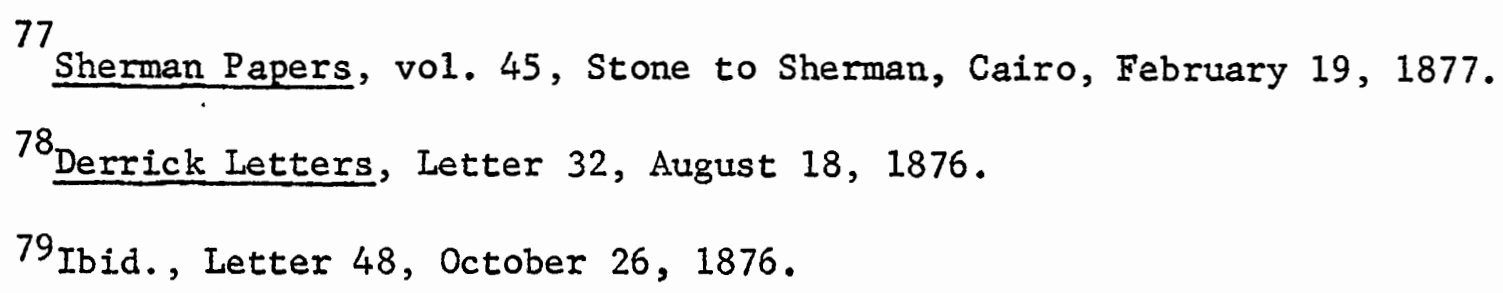


settlement, however, did not occur until after the American officers were officially discharged from the Egyptian service.

An even more direct retaliation against the American officers came when Colonel Dye was ordered to stand court martial. A native officer of low rank accused Colonel Dye of striking him during the Abysinian campaign for no apparent reason. It appeared that Dye, so frustrated with the man's incompetence and carelessness, had slapped the officer when he discovered an important box missing. Due to the highly emotional atmosphere in Cairo at the time, Dye refused to submit to the court martial even though General Stone had managed to place two American officers on the four man tribunal. Instead, Dye chose the protection of the American Consul General. Apparently, Colonel Dye was the sole American officer to demand the exclusion of the clause exempting the officer from his contract. After several interviews with Ismail, Consul General E. E. Farman was able to have the matter dropped. 80

The months that followed the Abyssinian affair were littered with such incidents, some minor in character, others more serious as in the Dye court martial. Amidst these insults, hardships and attacks, the American hopes to return to Abyssinia to complete the campaign slowly died. Ismail's desparate financial condition prevented the undertaking of any new military projects. Some of the engineers were allowed to

$$
{ }^{80} \text { Farman, p. } 196 .
$$


continue their mapping expeditions; however, most of the men found themselves with Iittle to occupy their time. A general dissatisfaction and a growing resentment directed against General stone spread amongst the officers. Many of the men felt that Stone was no longer promoting the American interests and that he was appropriating for himself the recognition for their own individual achievements.

Colonel Chaille-Long claimed that Stone had delayed the publication of one of his central African reports in order to claim the credit for himself at some later date. Even worse, Stone supposedly had promised him a promotion to brigadier general which never materialized. 81 ChailleLong resigned in his anger and blamed Stone for the deterioration of American morale in Egypt, insisting that Stone had become a "thorough Turk!"'82 Colonel Mason suspected that Stone was favoring Colonel Purdy's claims to African discoveries over his own, while Colonel Lockett described the change in Stone's character from "a kind, polished gentleman, in his outward demeanor to everybody," to a man who had ". . . so much dealings with slipperiness in Egypt (that) he has become slippery himse1f. ${ }^{83}$

It is difficult to gauge exactly what kind of role General stone

81 William Hesseltine, The Blue and Gray on the Nile (Chicago: University of Chicago Press, 1961), P. 229.

${ }^{82}$ Ibid., p. 230.

${ }^{83}$ Ibid. 
was now playing. It was only natural that the American officers, beset with financial problems and professional grievances came to him. In the past he had been the American Iiaison with the Khedive and Stone had always seemed to obtain satisfactory results. Now Stone's mediation met with little success. How much effort did Stone really expend on the part of the American officers? The number of his meetings with the Khedive may have decreased but he still saw Ismail with some degree of regularity. Was Stone actively pursuing the interests of his compatriots? Judging from the private letters and published articles of the various officers under Stone and from his own published articles and private letters to General Sherman, Stone's personal loyalties lay with the Khedive. He would do what he could for his fellow Americans, but he was more concerned with the well being of Ismail and his Khedival authority. In a letter home to his wife shortly before the final discharges, Lieutenent Colonel Henry Derrick tells of the various rumors circulating "in the streets" about the financial consolidation of the government and the impending dismissal of the Americans. He adds, however, ". . . it may be that all American officers except Stone, will be discharged. I do not think Stone will ever leave Egypt during the lifetime of the present Khedive, after his death and there comes a new king, who knows not Stone, things may be different. 84

\footnotetext{
${ }^{84}$ Derrick Letters, May 17, 1877.
} 
Stone truly believed in the same dreams as Ismail. All of the Khedive's plans to modernize and develop Egypt; the dams, the canals, the railroads, the industries, and the military were articles of faith to Stone and indicative of his cultural heritage as an American. Stone could identify with Ismail on this plane in a way no European advisor with divided loyalties could. The absence of American interests in Egypt allowed Stone's complete support for Ismail's plans. Furthermore, the Khedive's optimism and his seemingly endless capacity for digesting or inventing new ideas appealed to Stone's very American character. 85 Stone was not the only American who believed in the good intentions of the Khedive, but he was the only one who maintained close enough contact with Ismail to have his sense of accomplishment continually reinforced. The pessimistic atmosphere of Cairo had less of an effect upon Stone than it did on the more isolated American officers under him. Stone may even have felt the American officers, with all their grumbling and dissension, were deserting the Khedive and his plans in his hour of need. Thus, as it became more and more clear that the Americans

\section{5}

Public Record Office E. O. Archives, 78/2855, July 6, 1878. Vivian to Marquis of Salisbury, no. 234. (As taken from the personal notes of Dr. Frederick J. Cox.) "The Khedive informed me in confidence some time ago that he had desired Prince Hassan to ascertain during his stay in England whether in place of these officers (the Americans) any English officers on half pay would consent to take service in his army on reasonable terms, and whether he could obtain permission to do so." The Khedive simply never gave up the conviction that he could weather the financial crisis he had created with all of his plans! 
would have to be dismissed in the new financial shakeup, Stone chose to stay and support what was left of Ismail's progressive regime. Stone would do what he could to help settle with the remaining American officers, but he felt that the plans and programs established by the Khedive must come first. 86

While Stone's personal contact with the Khedive helped sustain his support, it did not spread to his less-privileged American officers. Subjected to every form of humiliation short of physical detention the rest of the American officers were discouraged and restless. The antagonistic atmosphere created by the combined efforts of the native pashas and the predatory Europeans had its desired effect. By the end of 1877, seven of the remaining twenty-one officers had resigned: Colonel Chaille-Long, Colonel Lockett, Major Hall, Major Dennison, Surgeon-Major Wilson, Captain Porter, and Dr. Thomas D. Johnson. Rumors of the impending dismissal of the American officers flourished but only Colonel Field and Major Martin actually received their discharges in $1877 .^{87}$

${ }^{86}$ The depth of Stone's respect for the Khedive can be seen in the following excerpts from a letter to General Sherman. Sherman Papers, vo1. 50, Stone to Sherman, June 27, 1879. "His Highness the Khedive has fallen, as you already know, doubtless, by telegram. I write with sorrow in my heart, for by this foul act the combined powers of Europe have cast down the ablest and best ruler which the East has had since Muhammad Ali. . So the sovereign I have loved to serve and who had done so much for Egypt passes into history where hes works will make him appear far higher and nobler than the sovereigns and statesmen who have accomplished his overthrow. . ."

87 The Derrick Letters, 非13, March 30, 1877. 
With the circumstances surrounding the Americans as difficult as they were, it was no wonder that many of the officers viewed Stone in a negative light. His continuing support of Ismail and his government of pashas throughout the Egyptian financial crisis must have seemed like a sellout to the remnants of the American mission who had worked so hard to bring their modern, western ways to Egypt. These men were now worried about their future plans and their back pay while Stone continued to socialize with the pashas. In their eyes, Stone was acting more like a traditional pasha with each passing day, secure in his position of patronage and blind to the world around him. The American idealism that Stone still saw in the Khedive was lost upon the rest of the American officers.

The final discharges did not come until June 30,1878 , Without official warning, although the men had been expecting it for over a year, the remainder of the American officers were unceremoniously dismissed from the Egyptian service. The European controlled Commission of Inquiry, charged with the duty of cutting the Egyptian expenditures needed no encouragement to begin the economies with the dismissal of the foreign staff officers, who for the most part were American. General Stone was excluded from this order at the insistence of Ismail who still had faith in the loyalty and many abilities of his Chief of Staff. In short order the abolition of the few remaining vestiges of the American presence followed. The Staff College, the artillery school, 
the submarine school, the engineering school, the battalion school, and the children's school were eliminated to conserve the European bondholders money. ${ }^{88}$ The funding for the Printing Office established by General Stone was also halted, however it was able to continue with the revenue its publications generated. Thus the American mission disappeared in 1878 even more quickly that it had been established in 1870 . The Abyssinian debacle crystallized Khedive Ismail's precarious hold on his position as the absolute ruler of Egypt. He needed his pashas for support against the European infiltration of his government. The irregular and evasive habits so characteristic of the traditional pashas in bureaucratic and military positions in the Khedive's government were the only defense Ismail had to combat the thorough audit proposed by the British and French. These were the very traits the American officers had tried to modify. Ismail had no choice but to turn his back to the entire philosophy of the mission. While this did not preclude his private appreciation of the individual Americans, this change in events along with the financial cutbacks, effectively ended the unofficial American mission to Egypt.

$88_{\text {Hesseltine, p. } 249 .}$ 


\section{CHAPTER VI}

\section{CONCLUSION}

With the dismissal of the American officers from the Egyptian army in 1878, one of the earliest and most comprehensive experiments of sharing American military technology and organizational principles came to an end. After almost ten years of concentrated effort, the American officers left the Egyptian army in virtually the same condition as they had found it. During that time the American officers, led by General Charles P. Stone, designed a staff system for the Egyptian army and they established a series of specialized schools not only for the staff officers but for the rank and file as well. However, when these officers were given the opportunity to prove the effectiveness of their technology and organization in battle, they failed. Consequently, this early American attempt at sharing technology with a developing nation had little noticeable effect upon history. The American failure to effectively modernize and reorganize the Egyptian military system stemmed from three factors. The most destructive element was the resistance to change demonstrated by the traditional military elite of Egypt, the pashas. At issue here was not so much the technology offered by the Americans, but the cultural by-products of the American reorganization. Hundreds of years of traditional and religious pre- 
rogatives were at stake, and the Turkish and Circassian officers felt that there was little to gain in such a comprehensive overhaul of their system. The American insensitivity to the cultural. issues only strenghthened the pashas' resistance. Without the cooperation of the military elite, the American reforms had a minimal effect upon the Egyptian military system. The European objections to the American presence and their ultimate control of Egyptian finances proved to be the second insurmountable factor in the failure of the American mission. While the British and the French governments were not calling for the dismissal of the American officers on a daily basis, they certainly indicated their displeasure with Ismail's choice of independent military advisors. The need for a secure hold on Egypt increased as the British and French interests in Egypt expanded and as the stability of the Egyptian financial situation deteriorated. American support for the Egyptian government, however unofficial and limited, was unwelcome. Consequently, when Ismail lost the control of his treasury, the American mission was doomed to dismissal.

Ismail's continued vacillation between the pashas and the American officers under the ever present pressure from the European bondholders constituted the third reason for the American failure in this experiment. On the one hand, the Khedive believed in and encouraged the methods and goals of his American officers, yet on the other hand, he did not always recognize the consequences of the American proposals. In the early years of the mission, Ismail tended to support the American projects against the collective will of his pashas. However, as the European 
financial encroachment reached the critical stage, Ismail turned to his native pashas as his last line of defense. The American effectiveness declined with their influence, thus insuring their final dismissal from the Egyptian army.

Although they failed in the larger cultural and political sphere of their mission, their technology prevailed wherever the Americans were given a free reign. The refortifications, roads, canals, dams, and light houses would remain in Egypt, the Sudan, and Ethiopia as a testament to the American engineering capacity. The territorial maps, the hydrological maps, and the geological assay reports that resulted from the various exploration assignments brought the study of the African continent into new heights of scientific precision. In spite of the cultural difficulties, as technicians, the Americans performed admirably. An assessment. of the American mission's effect upon Egyptian history would not be complete without raising one further question. Did the educational programs established by the American officers have any effect upon the Egyptian military? While recognizing that there was substantial disapproval by the traditional military elites to the various schools and that the schools were in operation for only six to eight years thus limiting their impact, does not totally preclude the possibility that the Americans did influence some of their students. The young Egyptian officers who were not from the traditional military families might have seen much to gain from the American programs. Unfortunately, speculation had now taken the place of concrete, available 
sources. However, if one follows this line of thought, some interesting coincidences in subsequent Egyptian history take on a less random appearance.

Approximately four years after the dismissal of the American mission a full-scale Egyptian military uprising took place, known as the Arabi rebellion. The leader, Colonel Ahmed Arabi was an Egyptian soldier who had risen to the rank of Lieutenant Colonel during the reign of Ismail's predecessor, Said Pasha. Because of his high rank, it is unlikely that he attended any of the American staffed schools, however it is documented that Colonel Arabi dealt with the American officers on a number of occasions. $^{1}$ Two specific details of the uprising suggest that Arabi had been influenced by the Americans.

In the first case, Colonel Arabi had accurate knowledge of the torpedo mines that were laid by the Americans some ten years earlier in Alexandria harbor. ${ }^{2}$ His efforts to secure the detonator device were foiled, but had he succeeded, the bombardment of the Alexandria harbor by the British and the French might have never occurred. The second detail concerns Arabi's last stand against the British at Tel-el-Kebir. General Stone conceived that very strategy in 1871. Unfortunately,

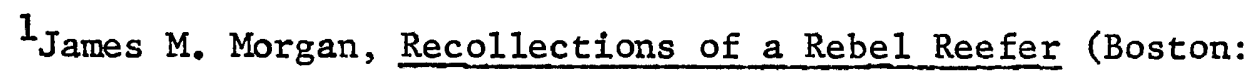
Houghton Mifflin Co., 1917), pp. 290-292.

2 Baron de Kuse1, An Englishman's Recollections of Egypt 1863-1887 (London: John Lane, The Bodley Head, 1914), pp. 150-151. 
Arabi failed to follow Stone's defense plan to the letter. By not fortifying Tel-el-Kebir and Zagazig (in the rear) as Stone suggested, Arabi left his army unprotected in the flat Delta against the advancing. British troops. Consequently the rebellion was crushed. 3

In both instances, the leftover American influence comes more as "what could have been" rather than what was actually achieved. That might be called the theme of the American's efforts in Egypt.

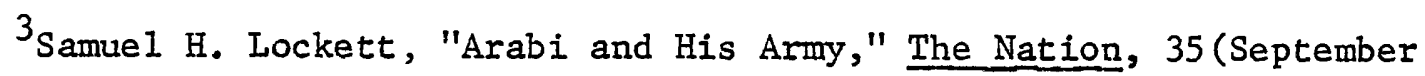
$28,1882)$, p. 258 . 


\section{SELECTED BIBLIOGRAPHY}

\section{Books:}

Annual Reports of the Association of Graduates. West Point, New York: U. S. Military Academy, 1887, 1901, 1904, 1917, 1925, and 1926. The Annual Reports include the obituaries of most West Point officers, written by classmates. A comraderie existed among the West Pointers who went to Egypt and most of the obituaries were written by their fellow officers with Egyptian service.

Archer, Thomas. The War in Egypt and the Soudan. London: BIackie \& Son, 1885 .

A British, anti-slavery rendition of Khedive Ismail's campaigns in central Africa.

Baddour, Abde1-Fattah. Sudanese-Egyptian Relations. The Hague: Martinus Nijhoff, 1960.

Unable to obtain.

Be11, Charles F. Mober1y. Khedives and Pashas: Sketches of Contemporary Rulers and Statesmen. London: Sampson Low, Marston, Searle, \& Rivington, 1884.

Interesting anecdotes about the prominent men in Khedive Ismail's cabinet.

Chaille-Long, Charles. My Life on Four Continents, vol. I. London: Hutchins on and Co., 1912.

Although Chaille-Long's inflated view of his role in this story and his often slanderous remarks about his fellow Americans detract from the book, it is a valuable source since it is one of only five books written by a participant in the American mission to Egypt.

Collins, Robert 0 . and Tignor, Robert I. Egypt in the Sudan. Englewood Cliffs, N. J.: Prentice Hall, Inc., 1967. An interesting and helpful history of the period. 
Colvin, Auckland. The Making of Modern Egypt. London: Seely \& Co., Ltd., 1906.

Not applicable to this time period although Ismail is discussed in the introduction in a negative manner.

Crabites, Pierre. Americans in the Egyptian Army. London: George Rutledge \& Sons, Ltd., 1933.

This is the first history written about the American mission some fifty years later. Crabites was fortunate to have full access to the Abdin Archives, making this book unique. However, the author was careless with minor details and his overriding attitude is. often too patronizing and moralistic to fully appreciate his theories.

Crabites, Pierre. Ismail the Maligned. London: George Rutledge \& Sons, Itd., 1938.

Crabites defends Ismail's reign using the Cave Report as his primary evidence. It would have been more even-handed if he had used the Commission of Inquiry's report with its more comprehensive audit of the treasury.

Cromer, Earl of. Modern Egypt, vol. 1. New York: The MacMillan Company, 1908.

The chapters on Ismail's financial disasters are very helpful, as written by the man who eventually solved the Egyptian fiscal crisis.

Cullum, General George W. Biographical Register of the Officers and Graduates of the U. S. Military Academy, vol. III Supplement. New York: James Miller Publisher, 1879.

A listing of the graduates of the academy and their career assignments.

DeLeon, Edwin. The Khedive's Egypt. London: Sampson Low, Marston, Searle, \& Rivington, 1877.

DeLeon was a British citizen who served as an American Consul in Egypt for some years. He is sympathetic in his book to the American officers but he does not add much substance as a source.

Dicey, Edward. The Story of the Khedivate. New York: Charles Scribner's Sons, 1902.

Another personal account written about Egypt of that time. His dealings with the American officers were brief. 
Dodwe11, Henry. The Founder of Modern Egypt. Cambridge: Cambridge University Press, 1931.

An outstanding biography of Muhammad Ali. He discusses the military reforms in moderate detail.

Douin, Georges. Histoire du Règne du. Khédive Ismail, vols. 1-3. Rome: Societe Royale de Geographie d'Egypt, 1933-1936. The best and most comprehensive work on Ismail's reign in general and his African empire in particular. His description of Ismail's political relations with the Porte and of the Americans officers and the Abyssinian campaign are important.

Dye, William McE. Moslem Egypt and Christian Abyssinia. New York: Atkins and Prout, 1880; reprint ed., New York: Negro Universities Press, 1969.

Colonel Dye's unhappy Egyptian experiences prejudice the details throughout the book. Nevertheless, his vivid account of the Abyssinian campaign is one of the most important sources available.

Etheredge, Annie. "An Alabaman in Abyssinia." M. A. Thesis, University of Alabama, 1957.

A monograph on Colonel Samuel Lockett, she had extensive use of the private papers of Colonel Lockett and Lieutenant Colone1 Henry Derrick.

Farman, Elbert Eli. Along the Nile with General Grant. New York: The Grafton Press, 1904.

As the American Consul during the last years of the American military presence, Farman gives an on-the-spot travelogue of General Grant's post-presidential tour of Egypt.

Farman, Elbert Eli. Egypt and Its Betrayal. New York: The Grafton Press, 1908.

A firm supporter of Ismail, Farman's account of the Khedive's downfall is highly anti-British. He mentions a number of American officers' projects throughout the book.

Gordon, Lucie Duff. Letters from Egypt, 1862-1869. Re-edited with additional letters by Gordon Waterfield. New York: Praeger, 1969.

Lady Duff Gordon writes with an unusually sympathetic view of the Egyptian fellahin. She witnessed the hardships experienced by the peasants that stemmed from Ismail's modernization plans ans she presents a very convincing argument against overnight modern development plans. 
Hesseltine, William and Wolf, Hazel. The Blue and Gray on the Nile. Chicago: The University of Chicago Press, 1961.

This is the most recent and only book published about the American mission since the book by Pierre Crabites. As a Civil War historian, Hesseltine was able to trace the backgrounds of the veterans who went to Egypt in search of a job. The bibliography was particularly helpful although he did not have access to the Abdin Archives. In spite of the careful documentation, one should be wary of some of the conclusions he draws regarding Ismail and his cabinet. Hesseltine's theory concerning Ismail's objectives in Abyssinia goes directly counter to the evidence presented by both Loring and Dye, the primary sources we have at this time.

Heyworth-Dunne, J. An Introduction to the History of Education in Modern Egypt. London: Luzac \& Co., 1938.

A good source for both the history of education in Egypt under Ismail and the efforts at military reform by Muhammad Ali.

Holt, P. M. Egypt and the Fertile Crescent, 1516-1922. Ithaca:

Corne11 University Press, 1966.

Holt stresses the theory that Ismail wanted to control the coast of Africa and the southern entrance to the Suez Canal.

Kuse1, Baron de. An Englishman's Recollections of Egypt, 1863-1887. London: John Lane, The Bodley Head, 1914.

Primarily a personal account, de Kusel does however complete the history of John Lay's torpedo mines. He destroyed the detonating device prior to the bombardment of Alexandria harbor.

Landes, David. Bankers and Pashas. Cambridge: Harvard University Press, 1958.

An excellent portrayal of the development of Ismail's financial problems.

Langer, William L. The Diplomacy of Imperialism. New York: Alfred A. Knopf, 1951.

This book contains an interesting discussion of the "unity of the Nile valley" concept.

Lewis, Lloyd. Sherman: Fighting Prophet. New York: Harcourt Brace and Company, 1958.

Sherman's biography with no mention of his 1872 trip to Egypt. 
Loring, William Wing. A Confederate Soldier in Egypt. New York: Dodd, Mead, \& Co., 1884.

One of the five books by the participants, Loring's description of the Abysinian campaign does not always resemble Dye's, but between these two accounts a fairly clear picture of the fiasco emerges. Douin uses these two almost exclusively for his discussion of the Abyssinian campaign.

Marlowe, John. Spoiling the Egyptians. New York: St. Martin's Press, 1975.

A useful book, particularly on Africa.

McClellen, George Brinton. McClellen's Own Story. New York: Charles L. Webster \& Company, 1887.

The story of Ball's Bluff from the commander's point of view is useful. He also assesses stone's character in a complimentary fashion.

McCoan, J. Carlisle. Egypt As It Is. London: Cassell Petter \& Galpin, 1877.

This was the first edition of a book revised three times. In this edition he was fairly enthusiastic about Ismail's development plans, but by the third edition the imminent bankruptcy of Egypt had soured his observations.

Merrill, James M. William Tecumsah Sherman. Chicago: Rand McNally \& Company, 1971. either.

This biography does not mention the 1872 Egyptian trip

Morgan, James Morris. Recollections of a Rebel Reefer. Boston: Houghton Mifflin Company, 1917.

Morgan's exploits make good copy, a very engrossing book and as a participant, a very important book.

Sabry, M. L'Empire Égyptien sous Ismäil et L'Ingérence Anglo-Francaise.

Paris: Libraire Orientaliste Paul Geuthner, 1933.

Along with Douin, this book was one of the most useful histories of the time period.

Shukry, M. F. The Khedive Ismail and Slavery in the Sudan: 1863-1879.

Cairo: Librarie La Renaissance d'Egypt, 1937.

Not able to obtain.

Vatikiotus, P. J. The Modern History of Egypt. New York: Praeger, 1961.

A general history. 
Wallace, D. MacKenzie. Egypt and the Egyptian Question. London: MacMillan Co., 1883.

He does not discuss the Americans.

Warren, Edward. A Doctor's Experience in Three Continents. Baltimore: Cushings \& Bailey, 1885.

A character in his own right, Warren's description of his experiences in Egypt add to the total impression of the American mission as it functioned in Egypt. His dislike of Stone tends to predjudice some of his opinions.

Periodicals and Encyclopedias:

Abir, M. "Ethiopian-Egyptian Border Problems." Journal of African History 8, no. 3 (1967): pp. 443-461.

A history of the Egyptian efforts to expand into Abyssinia during Muhammad Ali's reign.

Batcheller, 0. A. "The Bombardment of Alexandria." Century Magazine 28(October, 1884): p. 956.

A letter of support for General Stone's account of the bombardment.

Chaille-Long, Charles. "Colonel Chaille-Long on the Juba." Journal of the American Geographical Society of New York 19 (June, 1887): pp. 194-198.

Chaille-Long claims that he obeyed Ismail's instructions to the letter and that Ismail used him as a scapegoat when the expedition was forced to return.

Chaille-Long, Charles. "England in Egypt and the Sudan." North American Review 168(May, 1899): pp. 570-580.

Chaille-Long claims that the English were planning to take over Egypt from the beginning.

Chaille-Long, Charles. "Princes of Egypt." Cosmopolitan 26(January, 1899): pp. 253-262.

An interesting article on the members of the Muhammad Ali dynasty.

Colston, Raleigh E. "Modern Egypt and Its People." Journal of the American Geographical Society of New York 13(1881): pp. 133-164.

He gives a number of second hand details of the Abyssinian campaign and general information about the fellahin that made up the Egyptian army. 
Colston, Raleigh E. "Stone-Pasha's Work in Geography." Journal of the American Geographical Society of New York 19(1887): pp. 48-50. A very helpful, chronological listing of the various expeditions of the Third Section.

Cox, Frederick J. "The American Naval Mission in Egypt." Journal of Modern History 26(June, 1954): pp. 173-178.

A detailed description of the torpedo plans of John Lay in particular and an overall description of the naval programs of the American mission in general.

Cox, Frederick J. "Arabi and Stone: Egypt's First Military Rebel1ion, 1882." Cahiers d'Histoire Egyptienne 8(1956): pp. 155-175.

Publishes for the first time a letter by Stone that tells his view of the events of 1882 .

Cox, Frederick J. "Khedive Ismail and America, 1870: A Diplomatic Incident: L'Affair Butler." Cahiers d'Histoire Egyptienne 3(1951): pp. 374-381.

This article tells of Consul Butler's first blunder in the Egyptian court of Khedive Ismail.

Cox, Frederick J. "Khedive Ismail and Panslavism." The Slavonic and East European Review 78(December, 1953): pp. 151-167.

Ismail's relations with the Russian government are discussed.

Cox, Frederick J. "Munzinger's Observations on the Sudan, 1871."

Sudan Notes and Records 33(1952): pp. 189-201.

This article contains comments and a translation of Werner Munzinger's influential report on the Sudan.

Cox, Frederick J. "The Suez Canal Incident of 1874." Cahiers d'Histoire Egyptienne 4(1952): pp. 3-13.

This is the account of Ismail's attempt to capitalize on Ferdinand delessepps' miscalculations.

DeLeon, Edwin. "The New Egypt of Khedive Ismail." Appleton's Journa1 14 (August, 1875): pp. 207-208.

Unable to obtain.

"Egyptian Campaign in Abyssinia." Littel's Living Age 5th Series, 19(July-September, 1877): pp. 278-287.

This article contains a brief description of the battle by an unnamed staff officer. 
Encyclopedia of Islam, New Edition, S. v. "Ismail Pasha," by P. J. Vatikiotus.

Encyclopedia of Islam. 1937 ed., S. v. "Muhammad AIi."

Forbes, Archibald. "An American Criticism of the Egyptian Campaign." Nineteenth Century 16 (August, 1884): pp. 228-237.

An uninformed account of Commander Goodrich's approval of the British bombardment Alexandria.

Goodrich, C. F. "The Bombardment of Alexandria." Century Magazine 28(July, 1884): pp. 228-237.

Goodrich disputes Stone's narrative of the events before, during, and after the bombardment.

Green, Betty P. "The Bey from Virginia." Aramco World 25(1974): pp. $24-25$.

A brief account of Alexander McComb Mason's career in the Egyptian service.

Green, F. V. "American Influence in Egypt." Nation 32(February, 1881): p. 77.

A scathing review of William Dye's book.

Issawi, Charles. "Egypt Since 1800: A Study in Lop-Sided Development." Journal of Economic History 21(1961): pp. 1-25.

Excellent background material.

Jesman, Czeslaw. "American Officers of Khedive Ismail." African Affairs 57(1958): pp. 302-307.

A distinctly negative view of the American presence.

Jesman, Czeslaw. "Egyptian Invasion of Ethiopia." African Affairs 58(1959): pp. 75-81.

Jesman's bias against the Egyptians is extreme. He cites no bibliographical sources for his opinions.

Kenny, Lorne M. "Ismail's Dream of Civilization and Progress." Muslim World 55(1965): pp. 142-155, 211-221.

This article covers Ismail's non-military interests.

Lockett, Samuel H. "Arabi and His Army." Nation 35(1882): pp. 257-258. Lockett suggests that Arabi used Stone's plan for the defense of the Delta.

Luter, John. "Son of Egypt." Aramco World 23(1972): pp. 14-19. A brief but accurate article about General Stone's career. 
McClellen, George B. "A Winter on the Nile." Scribner's Monthly 13 (January, 1877): pp. 368-383.

Only the first few pages apply to the American mission, however, he does discuss his conversation with Stone about the American improvements in the education of the Egyptian soldiers.

The National Cyclopedia of American Biography, vol. 6 (1896), S. v. "Valetine Mott."

Robinson, A. E. "The Ethiopian-Egyptian War of 1874-1876." Journal of the African Society $26(1926)$. Unable to obtain.

Stanton, Colonel E. A., (translator). "Secret Letters from the Khedive Ismail in Connection with an Occupation of the East Coast of Africa." Journal of the Royal African Society 34(1935): pp. 269-282.

Interesting background material.

Stone, Charles P. "The Bombardment of Alexandria." Century Magazine 28(October, 1884): pp. 953-956.

Stone's account of the bombardment in which he blasts the British for their intervention.

Stone, Charles P. "The Climate of the Egyptian Sudan." Science 5(Apri1, 1885): pp. 268-271.

A technical piece.

Stone, Charles P. "Military Affairs in Egypt." Military Service Institution of the United States Journal 5(1884): pp. 154-183.

Stone's recollections of his work in the Egyptian services. A primary source for the details of the reorganization of the Egyptian army.

Stone, Charles P. "The Political Geography of Egypt." Journal of the American Geographical Society of New York 15(1883): pp. 361-374. Stone's interpretation of Ismail's contributions to Egypt.

Stone, Charles P. "The Route from Suakin to Berber." Science 5(April, 1885): p. 290.

A scientific piece which explained the difficulties of the British soldiers who were currently roaming about the area with no water and extreme heat. 
Stone, Fannie. "Diary of an American Girl in Cairo During the War of 1882." Century Magazine 28 (June, 1884): pp. 288-302.

An account of the Stone family's experience in Cairo during the bombardment of Alexandria.

Thurneyssen, Fritz von. "L'expedition de 1'Egypte contre 1'Abyssinie 1875-76." Bulletin de 1'Institut Egyptian 5th Series, 5(1911): pp. 19-29.

A very interesting article written by an Austrian staff officer about the Abyssinian campaign. A straight forward account without any personal details, it is somewhat disappointing.

Turton, E. R. "Kirk and the Egyptian Invasion of East Africa in 1875: A reassessment." Journal of African History 11(1970): pp. 355-370.

A well documented and important article that destroys a number of Chaille-Long's assertions.

Williams, Harry. "Investigation 1862." American Heritage 6(December, 1954):- pp. 17-21.

The full account of Stone's Ball's Bluff experience.

Unpublished Manuscripts, Archival Material, and Newspapers:

Cairo, Egypt. Abdin Archives, Periode Ismail, 1870-1876. Obtained from the private notes of Dr. Frederick J. Cox.

Chapel Hill, North Carolina. University of North Carolina. Southern * Historical Collection. The Samue1 P. Lockett Papers. Obtained from the private notes of Dr. Frederick J. Cox.

Great Britain, Public Record Office. Foreign Office Archives. Selected entries obtained from the private notes of $\mathrm{Dr}$. Frederick J. Cox and Mr. Robert Hunter.

Henry C. Derrick, letters to his wife, in private, family possession. Obtained from the private notes of Dr. Frederick J. Cox.

Times (London). 1876-1878.

Times (New York). 1870-1876.

U. S. Department of State. United States Consular Despatches in Alexandria, Egypt, 1835-1873, vols. 5-7. 
U. S. Department of State. United States Consular Despatches in Cairo, Egypt, 1864-1906, vols. 8-16.

Washington, D. C. Library of Congress Archives. William T. Sherman

Papers, 1868-1885. Obtained from the private 1ibrary of $\mathrm{Dr}$. Frederick J. Cox. 


\section{APPENDIX 1}

ROSTER OF THE UNOFFICIAL AMERICAN MISSION TO EGYPT

* Vanderbilt Allen (West Point, Class of 1864)

1870: Arrived in Egypt

1872: Resigned

* James Bassel (West Point, Class of 1867)

1874: Arrived in Egypt

Resigned

+ William P. A. Campbell

1870: Arrived in Egypt

1874: Died in Khartoum, October 10

* Charles Chaille-Long

1870: Arrived in Egypt

1877: Resigned

+ Raleigh E. Colston

1873: Arrived in Egypt

1878: Discharged

Captain Coppinger

1875: Arrived in Egypt

1875: Resigned

* James A. Dennison (West Point, Class of 1870)

1875: Arrived in Egypt

1876: Left Egypt, December 31

+ Henry C. Derrick

1875: Arrived in Egypt

1878: Discharged

+ William W. Dunlap

1871: Arrived in Egypt

No record of departure 
APPENDIX 1 , continued

* William McE. Dye (West Point, Class of 1853)

1873: Arrived in Egypt

1878: Discharged

* Eugene Oscar Fechet (West Point, Class of 1868)

1872: Arrived in Egypt

1874: Left Egypt, February 14

+ Charles W. Field (West Point, Class of 1849)

1875: Arrived in Egypt

1877: Discharged

+ Charles I. Graves

1875: Arrived in Egypt

1878: Discharged

+ Wilburn B. Hall

1874: Arrived in Egypt

1877: Resigned

+ Cornelius Hunt

1870: Arrived in Egypt

1873: Died in Alexandria, February 28

* Henry Irgins

1876: Arrived in Egypt

1878: Discharged, died in Liverpool enroute to U.S.

+ Walter H. Jenifer

1870: Arrived in Egypt

1871: Resigned

+ Thomas D. Johnson

1875: Arrived in Egypt

1877: Resigned

+ Beverly Kennon, Jr.

1870: Arrived in Egypt

1874: Resigned

Robert S. Lamson

1875: Arrived in Egypt

1876: Died in Darfur, November 
APPENDIX 1, continued

+ Samuel H. Lockett (West Point, Class of 1859)

1875: Arrived in Egypt

1877: Resigned

+ William $W$. Loring

1870: Arrived in Egypt

1878: Discharged

* Charles F. Loshe

1875: Arrived in Egypt

1878: Died in Suakin, October

Harry McIvor

1870: Arrived in Egypt

No record of departure

* Chancellor Martin (West Point, Class of 1868)

1874: Arrived in Egypt

1877: Resigned

+ Alexander McComb Mason (Appointed to Annapolis 1861, resigned

1870: Arrived in Egypt

$$
\text { to enter the Confederate service) }
$$

1878: Discharged

+ James M. Morgan (Annapolis)

1870: Arrived in Egypt

1872: Resigned

* Thaddeus P. Mott

1869: Arrived in Egypt

1875: Retired to Turkey

* Edmund Parys

1871: Arrived in Egypt

1874: Died in Egypt, April 13

* David E. Porter

1875: Arrived in Egypt

1876: Resigned 
APPENDIX 1 , continued

* Henry C. Prout

1872: Arrived in Egypt

1878: Discharged

* Erastus Sparrow Purdy

1870: Arrived in Egypt

1878: Discharged, died in Cairo (as a civilian employee of the Khedive) June $21,1881$.

* Horatio B. Reed

1874: Arrived in Egypt

1875: Sick leave to U.S.

+ Alexander W. Reynolds (West Point, Class of 1838)

1870: Arrived in Egypt

1876: Died in Alexandria, May 26.

+ Frank A. Reynolds (West Point, Class of 1861)

1870: Arrived in Egypt

1875: Died in Illion, New York still in the Egyptian service

+ Thomas G. Rhett (West Point, Class of 1845)

1870: Arrived in Egypt

1875: Resigned

* Robert M. Rogers (West Point, Class of 1867)

1874: Arrived in Egypt

1875: Resigned

* Richard Savage (West Point, Class of 1868)

1872: Arrived in Egypt

1872: Returned in same summer

+ Henry H. Sibley (West Point, Class of 1838)

1870: Arrived in Egypt

1873: Discharged due to illness

* Charles Pomeroy Stone (West Point, Class of 1845)

1870: Arrived in Egypt

1883: Resigned

* Washington Carroll Tevis (West Point, Class of 1849)

1872: Arrived in Egypt

1873: Resigned 
APPENDIX 1, continued

+ William H. Ward

1871: Arrived in Egypt

1878: Discharged

+ Edward Warren

1873: Arrived in Egypt

1876: Discharged

+ D. G. White

1875: Arrived in Egypt

1876: Deserted, December

* William H. Wilson

1875: Arrived in Egypt

1877: Resigned

Symbols:

* Union Army

+ Confederate Army

No symbol indicates no Civil War record

Sources:

Chaille-Long, Charles. My Life on Four Continents, vol. 1. London: Hutchins on and Co., 1912.

Cullum, General George W. Biographical Register of Officers and Graduates of the United States Military Academy, vol. III Supplement. New York: James Miller Publisher, 1879.

Hesseltine, William B. and Wolf, Hazel C. The Blue and Gray on the Nile. Chicago: University of Chicago Press, 1961.

U.S. Department of State. United States Consular Despatches in Alexandria, Egypt, 1835-1873, vols. 5-7. 